\title{
تعليم مهارة الوثب الطويل لذوي صعوبات التعلم باستخدام أسلوب العصف الذهني : دراسة
}

\section{ميانية بالمرحلة الابتدائية.}

$$
\text { أ.د أد/ جمال إمـام السيد على. أحمد عبدالله. }
$$

الباحث/ إبر اهيم كمال إبراهيم محمد عمر . اهند

| / / / مقدمة البحث:

1/1

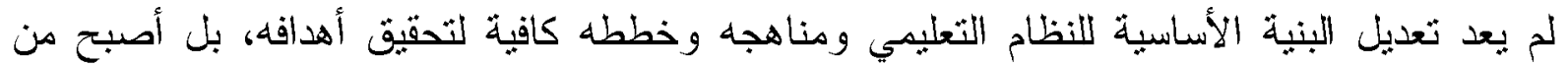

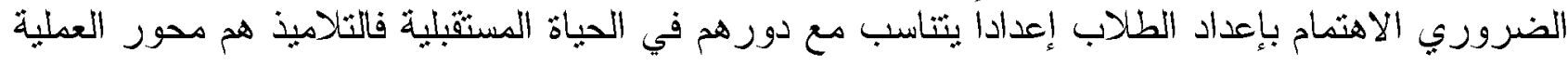

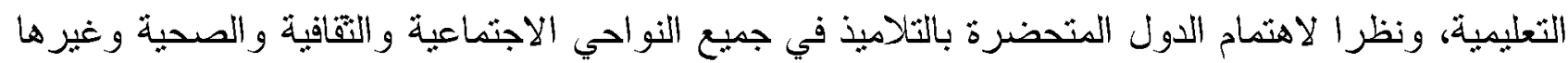
من النواحي الني تؤثر على شخصية التلميذ كعضو في جماعة المدرسة ، وعضو فئرة في المجنمع ككل، كانا

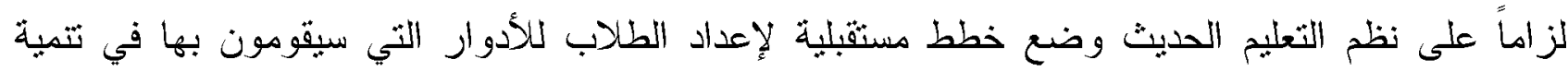
مجتمعاتهم، فالتلميذ هو الذى تعهد إليه الأمم شرف تتميتها وبنائها بالطريقة الحديثة وذلك بإعداده لكى يكون

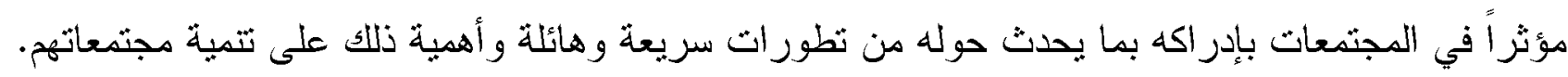
(r): (r)

و على الرغم من ثأكبد الاتجاهات الحديثة في التزبية على دور المعلم كونه محور العملية النعليمية إلا

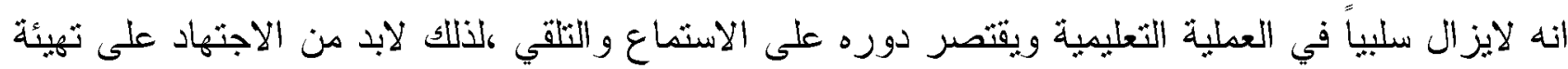

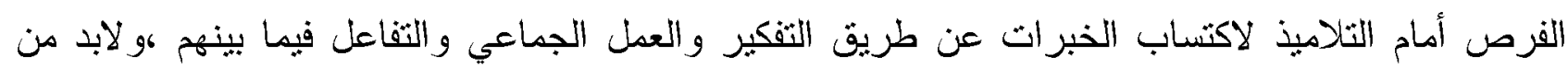

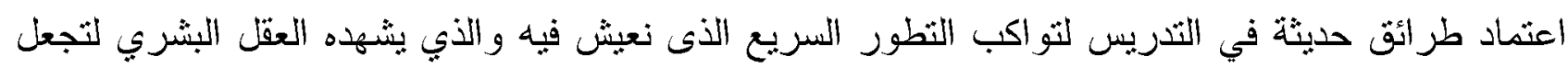

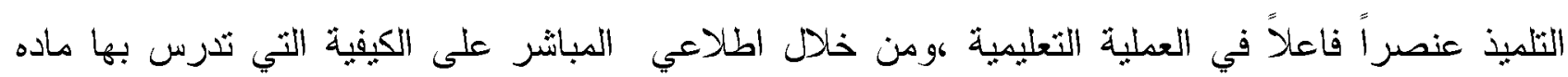

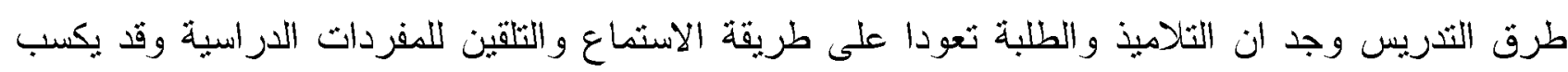

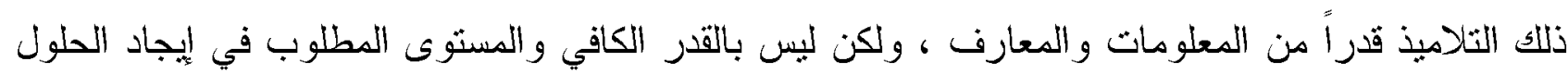
الابداعبة لها .

ومن هنا يسعى العاملون في ميدان المناهج وطرق التثريس إلي التوصل إلي استراتيجيات وأساليب

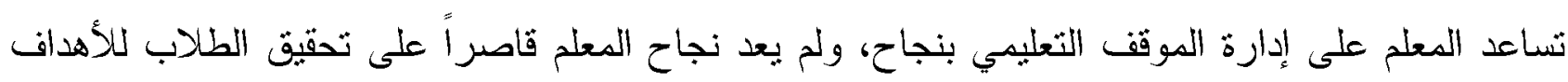

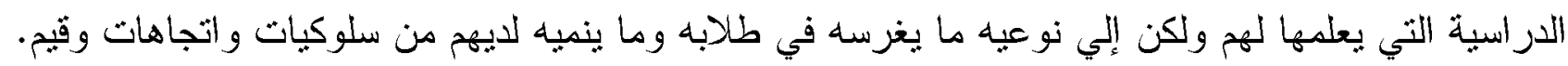

(ए)

ويذكر فتحي جروان (r + . r) أن العصف الذهني يعد من أكثر الأساليب المستخدمة في تحفيز

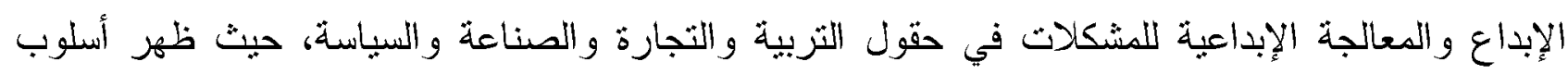


العصف الذهني في سوق العمل، إلا أنه انتقل إلي ميدان الثريية والتعليم وأصبح من أكثر الأساليب الثي حظيت باهنمام الباحثين و الدارسين. (• (: 10 (1) ويتفق كلا من طارق سويدان، محمد أكرم العدلوني (Y +. .rم) أن ( اليكس أزبورن ) يعد الأب الشرعي لطريقة العصف الذهني في نتمية التفكير الابداعي حيث جاءت هذه الطريقة كرد فعل لعدم رضاه

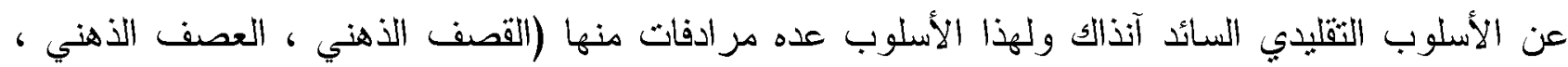

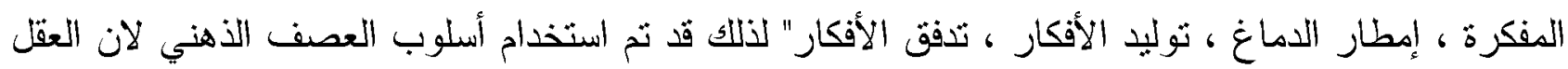

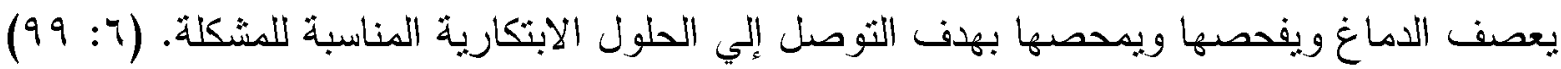

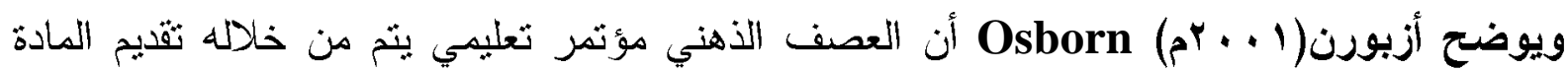

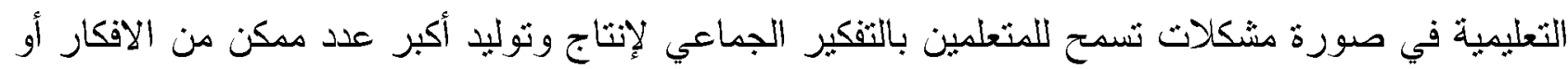

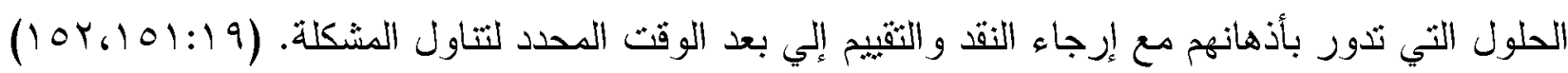

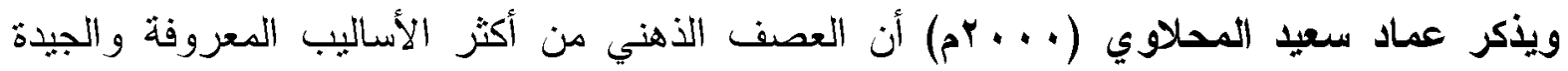

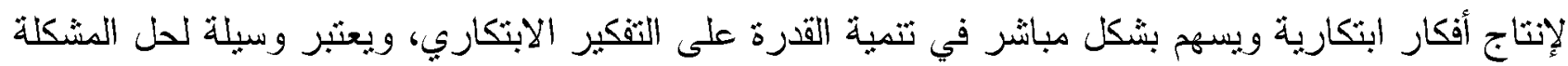

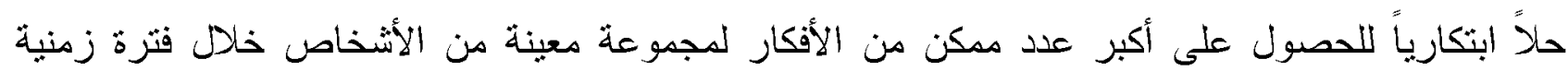
وجيزة. (9) (9)

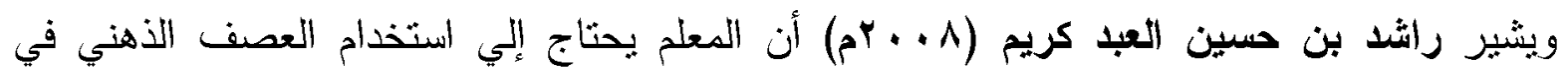
مو اقف كثبرة، وسيجد المعلم أن هذا الأسلوب مفيد لتولبد الأفكار والحلول للمشكلات كما يعمل على زيادة وتتمية التحصيل الدراسي للطلاب ويطرد الملل عنهم ويدفعهم إلي التحدي واستثارة الذهن للمشاركة بنشاط.

إن الأطفال ذوي صعوبات التعلم بعانون من خبرات الفتل المتكررة، والني ثقودهم إلي الاعثقاد بأهم

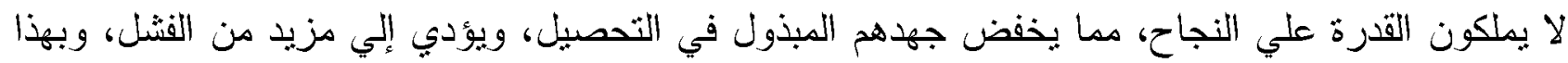
يجعلهم يدورون في حلقة مفرغة، ينخفض فيها مستوب الإنجاز لديهم عن المستوى المتوقع من جراء

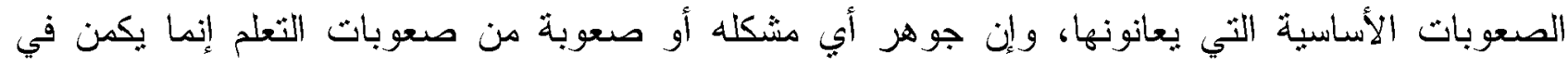

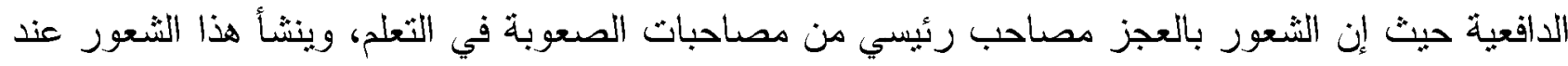
بأيه أي فثل في الوصول إلى مستوي منمكن لا بسنطيع المتعلم الوصول إليه، كما وصل إليه زملائه

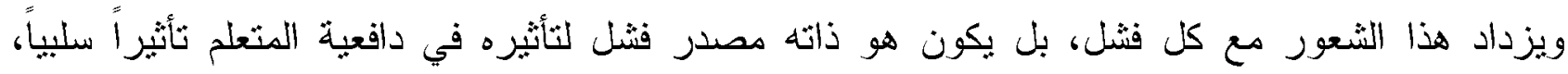

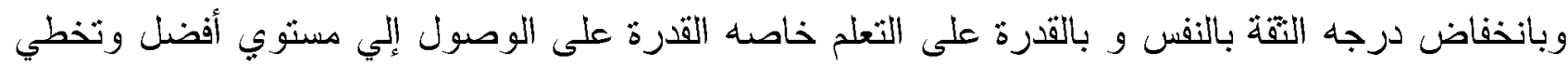
الصعوبات وبالتالي يصبح هذا العرض المصاحب لصعوبة النعلم هو نفسه مؤدياً إلي زيادة الصعوبة تعقبداً وتثابكاً. (VY: 
وفي الو اقع الحقيقي يوجد صعوبة كبيرة على تلاميذ ذوي صعوبات التحلم في إدراك جميع تفاصبل

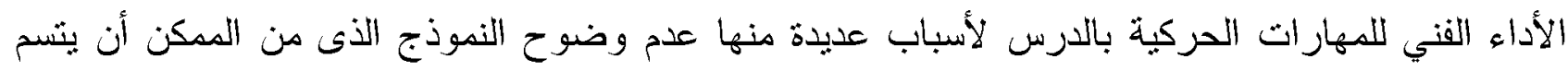

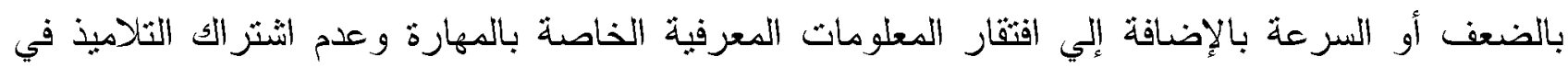
العملية التعليمبة أي يقوم المعلم بتتفيذ السلوكيات أو الخبرات التي بثناهدها التلاميذ دون تفكير .

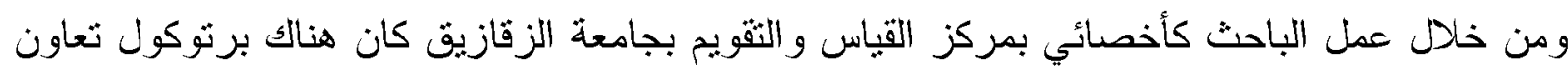

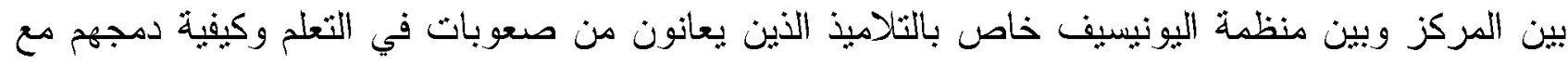

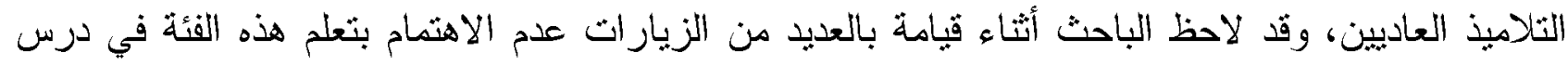

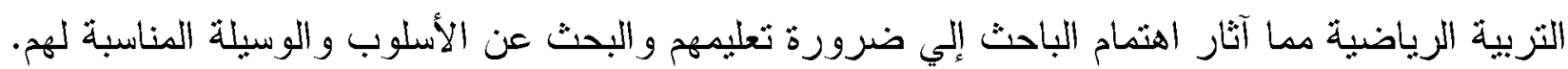

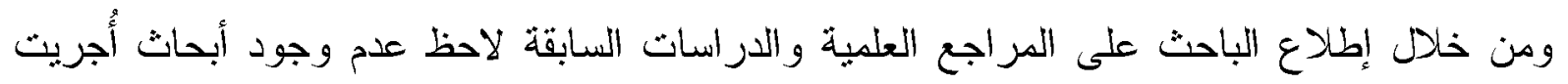
في مجال الثربية الرياضية بصفة عامة ومجال مسابقات الميدان و المضمار بصفة خاصة فيما يتعلق باستخدام

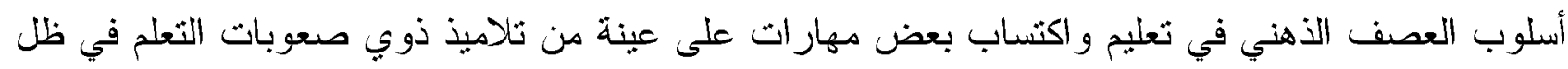

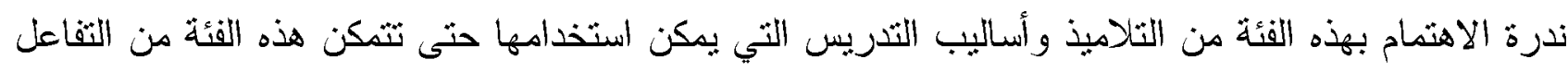

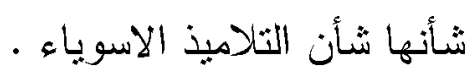

ومن خلال استخدام أسلوب العصف الذهني في درس النربية الرياضية لتعليم مهارة الوثب الطويل

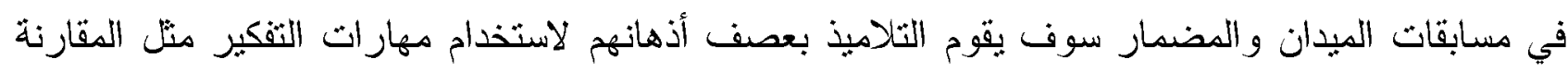

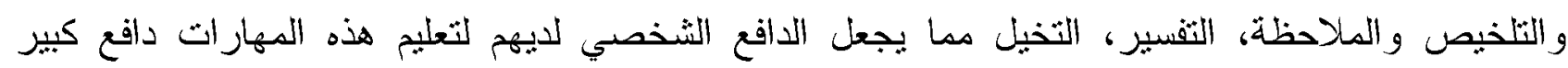
بساعدهم على العمل وجعل المهارات الثي يتعلمونها سهلة وميسرة وذلك من خلال أسلوب التفكير العلمي السليم الذى بساعدهم على تعليم وأداء مهارة الوثب الطويل علي أكمل وجه.

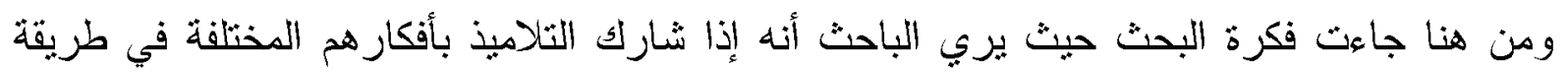

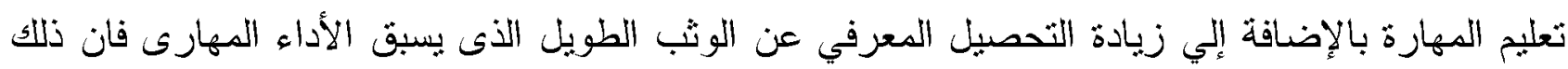

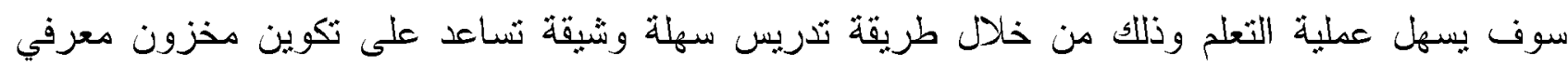

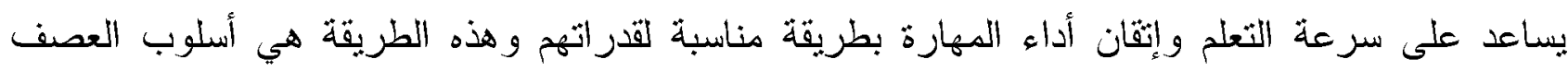
الذهني.

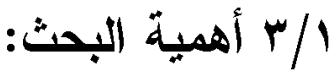

تتضح أهمية البحث في أن مهارة الوثب الطويل تتطلب توضيح دقيق وتدرج سهل في تعليم المهارة

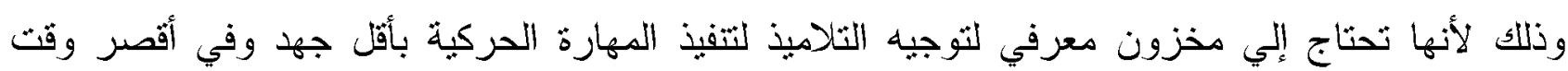

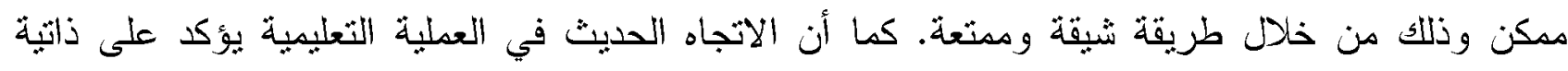

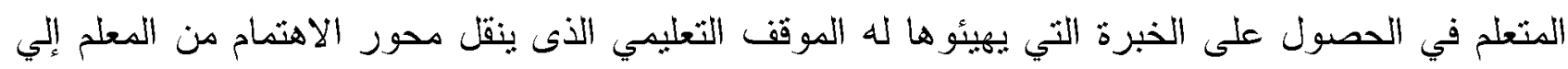
المتعلم ويجعله يقوم بدور إيجابي فعال ونتطظ.

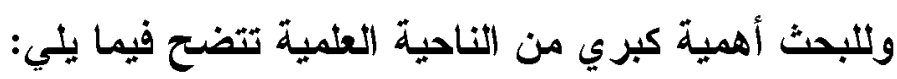


- البحث محاولة للوقوف علي مدي فاعلية أسلوب العصف الذهني في تحسين الأداء المهارى للوثب الطويل لتنلاميذ ذوي صعوبات التحلم بالمرحلة الابتدائية. - ترجع الأهمية العلمية لهذا البحث في إثراء الناحية المعرفية والعلمية لدي العاملين في مجال التدريس

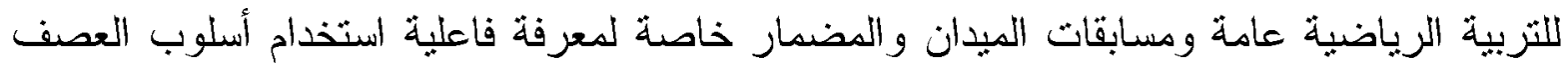

الذهني لتعليم مهارة الوثب الطويل لتلاميذ ذوي صعوبات التعلم بالمرحلة الابندائية.

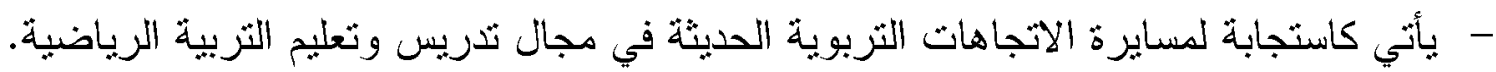
وللبحث أهمية كبري من الناحية التطبيقية تتضح فيما يلي: التئية - إعداد برنامج تعليمي باستخدام أسلوب العصف الذهني بمكن أن بستفيد منه الباحثين في إعداد برامج آخري. - نوجيه نظر المعلمين و القائمين علي العملية النعليمبة إلي إدراك فاعلية أسلوب العصف الذهني مقارنة بالأسلوب الثقليدي. - قد يسهم هذا النمط الجديد من نتفيذ أساليب النعلم باستخدام أسلوب العصف الذهني في نطوير وتدعيم مفاهيم التعلم في دجال تدريس أنثطة التربية الرياضية.

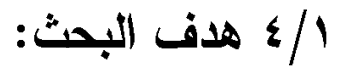

يهدف البحث إلي تصديم برنامج تعليمي باستخدام أسلوب العصف الذهني وذلك للتعرف علي: 1- تأثير استخدام أسلوب العصف الذهني علي المتغيرات البدنية و المستوي المهارى و الرقمي لمهارة الوثب

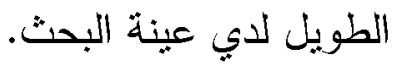
ب- تأثير استخدام الطريقة الثقلبدية (الاسلوب الأمري) علي المتغيرات البدنبة والمستوي المهارى والرقمي

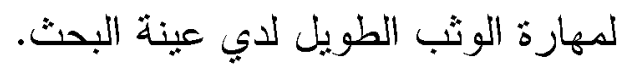
r- الفروق بين ثأثير استخدام أسلوب العصف الذهني والطريقة التقليدية (الأسلوب الأمزي) علي المثغيرات البدنية والمستوي المهارى و الرقمي لمهارة الوثب الطويل لدي عبنة البحث. ـ - وجود نسب تحسن متفاونة بين القياسين القبلي والبعدي في كل من المجموعتين التجريبية الضابطة في

$$
\text { جميع منغيرات البحث. }
$$

1- توجد فروق دالة احصائياً بين القباسين القبلي والبعدي للمجموعة التجرييية علي المتغيرات البدنية

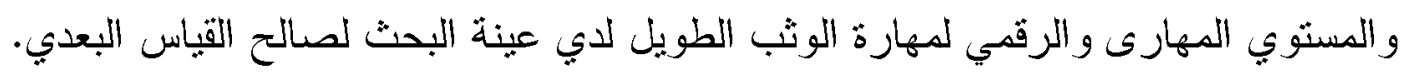

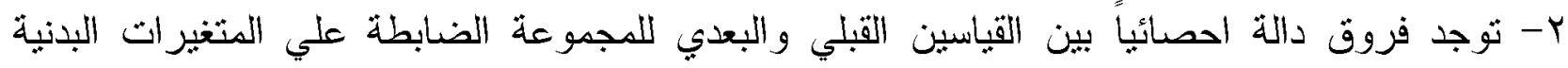
و المستوي المهارى و الرقمي لمهارة الوثب الطويل لدي عينة البحث لصنالح القياس البعدي. 
ب- ثوجد فروف دالة احصائياً بين متوسطي القياسين البعديين للمجموعنين التجريبية والضابطة علي

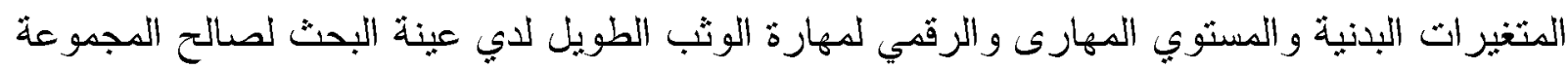

التجريبية.

ـ - توجد نسب تحسن متفاوتة بين القياسين القبلي والبعدي في كل من المجموعتين التجريبية الضابطة في

$$
\begin{aligned}
& \text { جميع منغير ات البحث. } \\
& \text { r/r الار اسات المرجعية }
\end{aligned}
$$

لقد أستعان الباحث من خلا الاطلاع علي الدوريات العلمية والدراسات المرجعية والثبكة الدولية

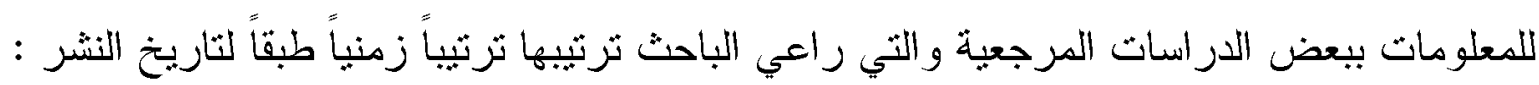

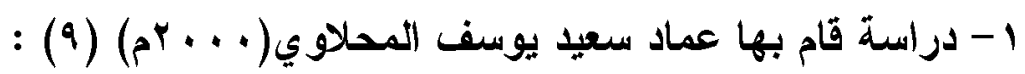
عنوان الدراسة: تأثير العصف الذهني للمشكلة والاكتثاف الموجه في كل من النحصبل الأكاديمي الابتكاري

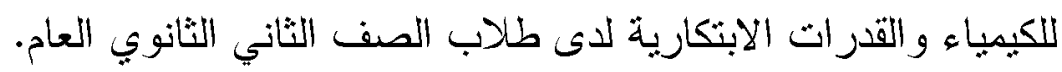
هاف الاراسة: هدفت إلي معرفة تأثير العصف الذهني للمثكلة والاكتئات الموجه في كل من التحصيل

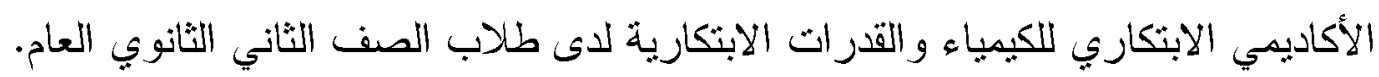

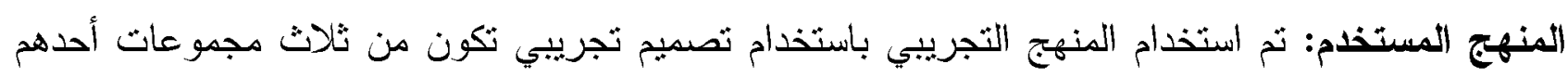

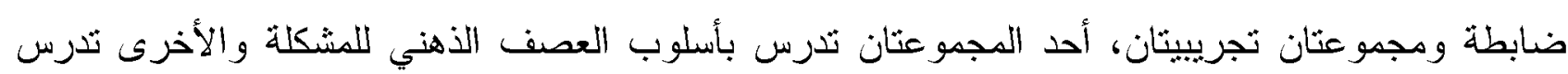
بالاكتثاف الموجه. العينة: نكونت العينة من (Y (9 ) ثلميذ من مدرستين مختلفتين بمحافظة كفر الشيخ.

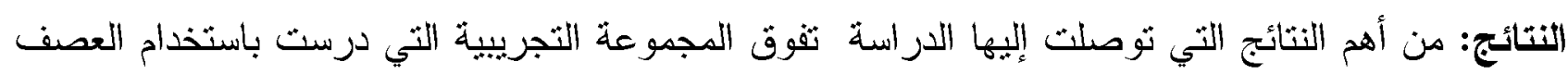
الذهني للمثكلة على باقي المجموعات في اختبار التحصبل الأكاديمي الابتكاري للكيمياء.

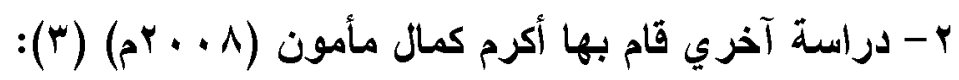

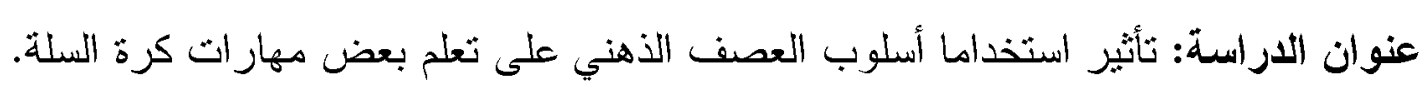

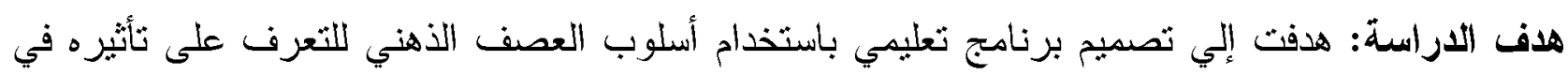

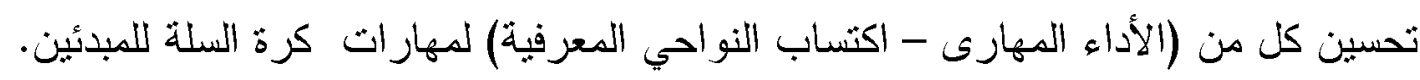

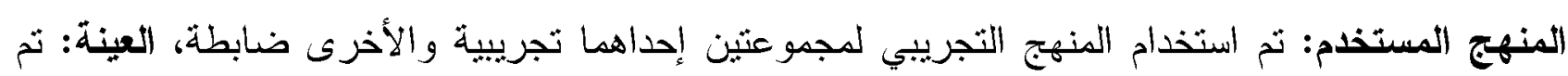

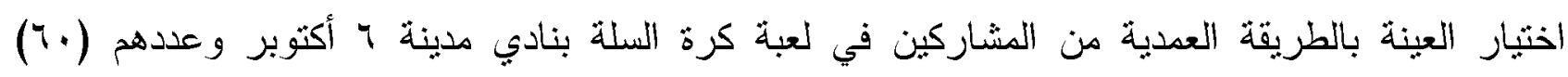
مبندئ. النتائج: أهم نتائج الدراسة التي نوصلت اليها إلي نسبة التحسن في مستوى الأداء المهارى والنواحي

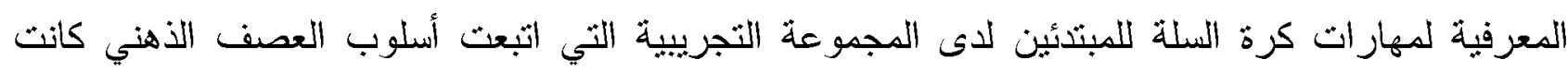
أفضل من نسبة التحسن بالآخرين.

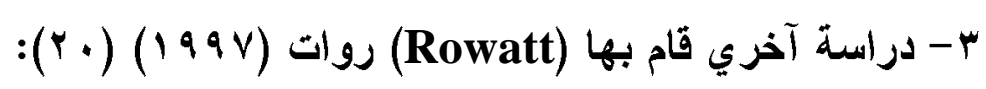


عنوان الاراسة: تأثثر استخدام أسلوب العصف الذهني الجماعي علي تتمية التفكبر الإبداعي.

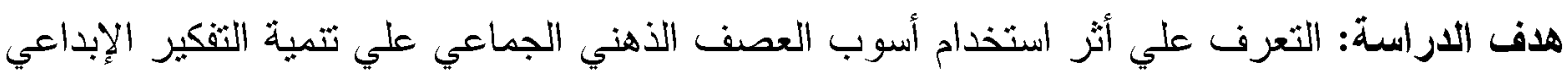

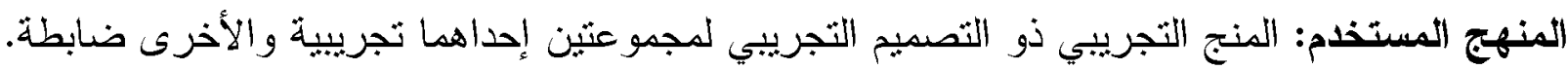
العينة: تكونت عبنة الدراسة من (70) طالباً معلماً نم اختبارهم عشو ائياً ممن يعتقا أن الأكثر أهمية في إنتاج

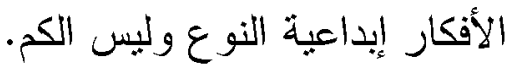
النتائج: أن الكم أقل من الكيف في نولبد الأفكار الإبداعية الجدبدة وأن العصف الذهني الجماعي يؤدي إلي التي تنمية التفكير الإبداعي ويعزز نوعية الأفكار فهو يعثد علي الكم ومنه ينولد الكيف وهذا من الإنداعه أهم مبادئه.

$$
\begin{aligned}
& \text { r/ ب إجراءات البحث } \\
& \text { 1/ 1/ منهج البحث: }
\end{aligned}
$$

تحقبقاً لأهداف البحث وفروضه استخدم الباحث المنهج التجريبي نظراً لملائمته لطييعة البحث ذو التصميم التجريبي لمجموعثين إحداهما تجريبية والأخرى ضابطة بنطبيق القياسات القبلية والبعدية للمجمو عتين.

\section{r/r}

أنتنمل مجنمع البحث على تلاميذ الصف السادس الابتدائي بمدرسة أولاد عمر الابتدائية للتعليم

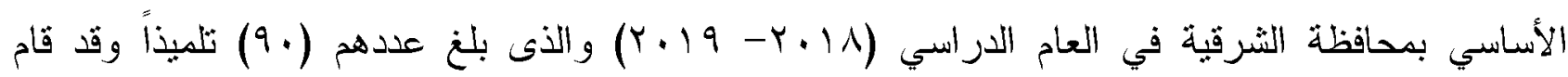
الباحث باختبار عينة البحث بالرجوع إلي شئون الطلاب بالمدرسة لمعرفة التلاميذ الذين لديهم صعوبات في الدي

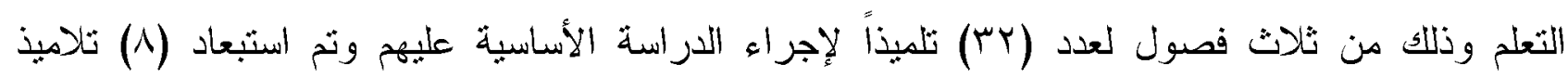

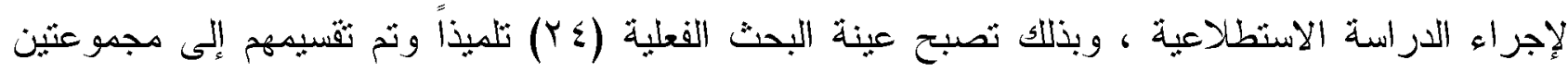
إحداهما تجريبيه ويستخدم معها التذريس بطريقة العصف الذهني و المجموعة الثانية الضابطة ويستخدم دعها الأسلوب التقليدي وقو ام كل منهما (Y ( ) تلميذاً بالإضافة إلي عينة مميزة عددها (^) تلاميذ من مجنمع البحث ليس لايهز صعوبات نعلم.

جدول (1)

\begin{tabular}{|c|c|c|c|c|c|c|c|c|}
\hline \multicolumn{2}{|c|}{ عينة البحث الكلية } & التجريبية البحث & عينة & الضابطة & عينة & سنطلاعية البحث & عينة & \multirow[t]{2}{*}{ عينة البحث } \\
\hline النسبة \% & العدد & النسبة \% & العدد & النسبة \% & العدد & النسبة \% & العدد & \\
\hline $1 \ldots$ & rr & rV.o. & ir & rV.o. & ir & ro... & $\Lambda$ & مجتمع \\
\hline
\end{tabular}

توصيف عينة البحث

r/ץ/ أدوات ووسائل جمع البيانات:

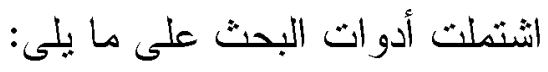

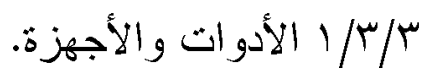


مجلة بحوث التربية الرياضية

ك/r/r/r الاستمار ات و المقابلات الثخصبة.

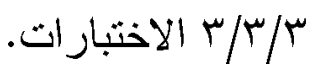

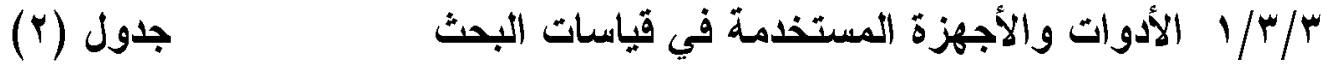

\begin{tabular}{|c|c|c|}
\hline وحدة القياس إن وجدت & الأجهزة والأدوات & م \\
\hline 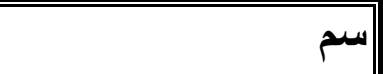 & جهاز الرستاميتر لقياس الطول & 1 \\
\hline كجم & ميزان طبى معاير لقياس الوزن & $y$ \\
\hline |سم & شريط قياس & $r$ \\
\hline 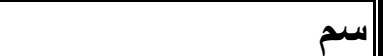 & مسطرة مدرجة لقياس المرونة & $\varepsilon$ \\
\hline ث & ساعة أيقاف & • \\
\hline- & مقاعد سويدية & 7 \\
\hline - & إلوحة ارتقاء. & $\mathrm{V}$ \\
\hline - & | أحبال مطاطية. & $\Lambda$ \\
\hline - & | صندوق مقسم. & 9 \\
\hline
\end{tabular}

r/ r/ الاستمارات والمقابلات الثخصية:

1 - استمار ات لتسجيل القباسات الخاصة بالبحث و هى كما يلى:

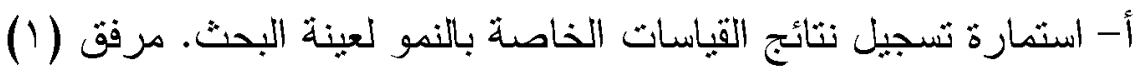

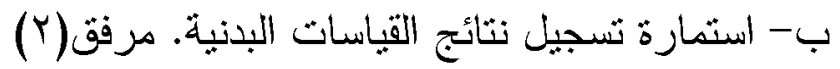

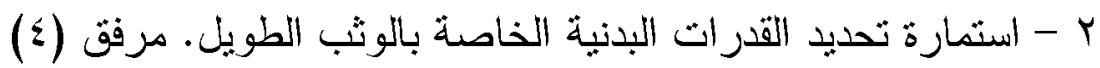

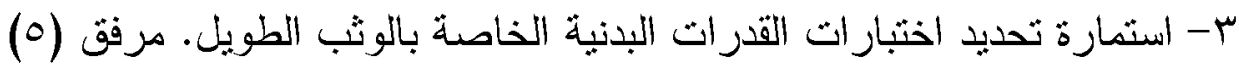

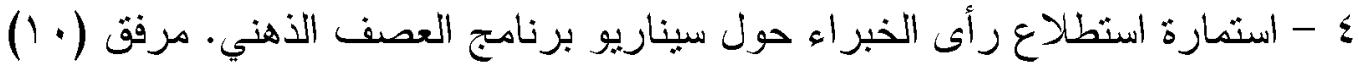

- استمارة تثييم مستوى الأداء المهارى والرقمي لمهارة الوثب الطويل. مرفق (11)

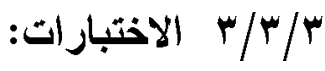

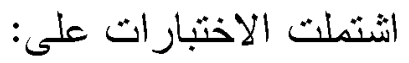

- الاختبار ات البذنية

تم تحديد الاختبارات البدنية الخاصة بالبحث وفقاً لما يلي:

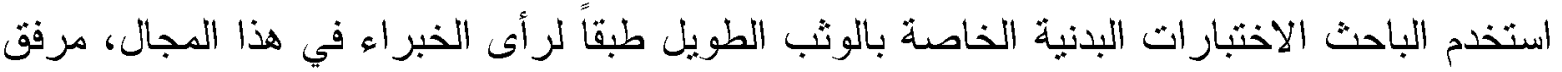

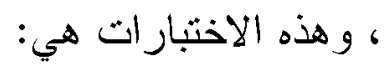

- اختبار السرعة: اختبار •ـ منر عدو من البدء المنطلق.

- اختبار القدرة العضلية: اختبار الوثب العريض من الثبات لقياس القدرة العضلية للرجلين. - اختبار المرونة: اختبار ثثى الجذع أماما أسفل من الوقوف الفيض. 
- اختبار الرشاقة: اختبار الجري الزجزاجي لقياس ددى قدرة التلميذ على تغيير اتجاه جسمه. - اختبار التو افق: اختبار الدوائر المرقمة لقياس نو افق الرجلين والعينين.

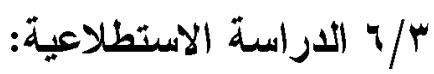

قام الباحث بإجراء الدراسة الاستطلاعية على (入) تلاميذ من خارج عينة البحث الأساسية لتطبيق

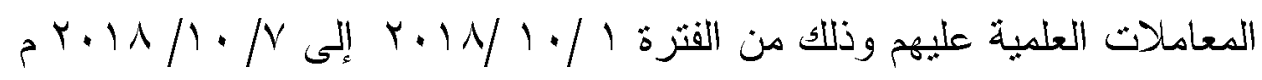

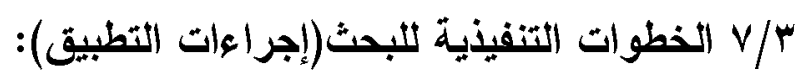
1/V/r قام الباحث بإجر اء القياس القبلي لعينة البحث التجريبية والضابطة وذلك بومي الأحد والأثثين بتاريخ

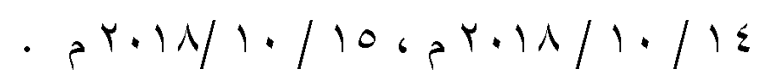
حيث ثم نشجيل قياسات التكافؤ بين المجموعثن قياسات قبلية لعينة البحث النجرييية والضـابطة في القدرات البدنبة و المستوي المهارى و الرقمي. 1/1/ / تنفيذ تجربة البحث الأساسية:

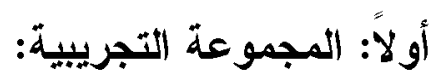

بعد أن تأكد الباحث من نكافؤ مجموعثي البحث (التجريبية والضابطة) قام بتتفيذ تجربة البحث

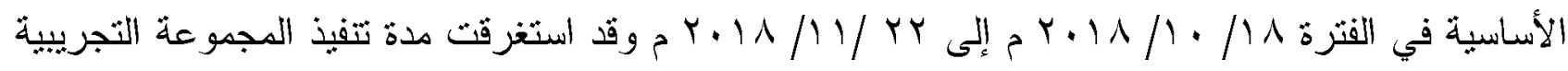

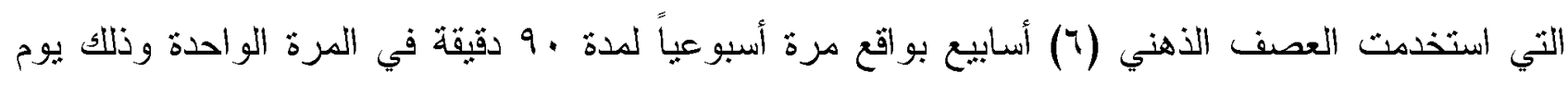
الخميس من كل أسبوع وتم النطبيق في آخر حصنين باليوم الدراسي بمدرسة أولاد عمر للتعليم الأساسي لئي بمحافظة الثرقية.

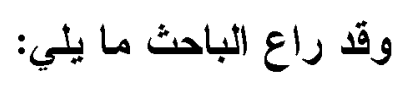

• أن يكون مكان جلسة العصف الذهني قريب من المكان المخصص للنطبيق العملي للوثب الطويل.

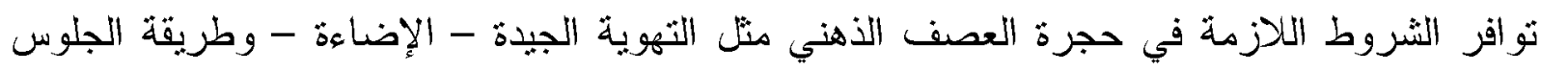

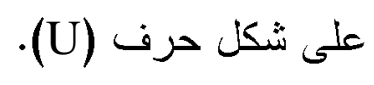

ثانياً: المجموعة الضابطة:

تم تعليم المجموعة الضابطة بالطريقة التقلبدية في نفس الفترة الزمنية السابقة مثل المجموعة النجريبية ولكن يوم الثلاثاء من كل أسبوع وقد ثم مر اعاة الأسس العلمية التالية : • قبام الباحث بالعملية التعليمية لتوحيد متغير التعلم.

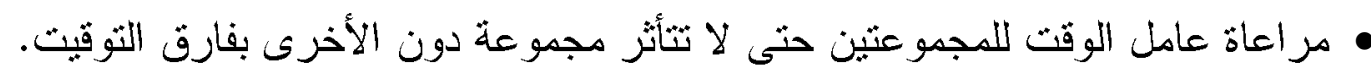
ت تجهيز الأدوات اللازمة ومكان التطبيق.

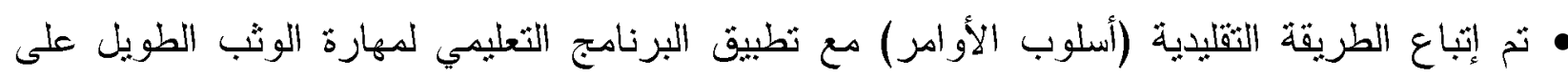

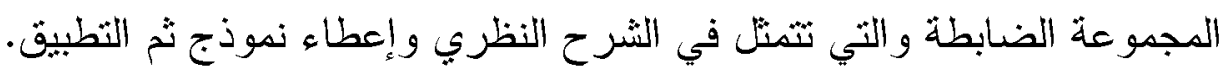


مجلة بحوث التربية الرياضية

1/ $1 / \mu$

قام الباحث بعد الانتهاء من التطييق بتجميع النتائج بدقة وجدولتها ومعالجنها إحصائياً وثم استخدام برنامج (SPSS) -للمعالجات التالية:

•

م الانحر اف المعياري.

• الوسبط.

• معامل الالثو اءء.

• اختبار "ت".

• معادلة النسب المئوية لمستوى التحسن.

\&/ · عرض ومناقشة النتائج.

1/2 عرض نتائج البحث.

جدول (r)

دلالة القروق بين القياس القبلي والبعدي في القدرات البلنية والمستوي المهارى والرقمي للوثب الطويل

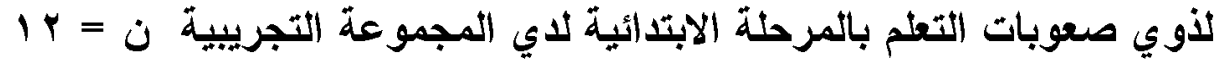

\begin{tabular}{|c|c|c|c|c|c|c|c|}
\hline \multirow{2}{*}{ "قيمة " ودلالتها } & \multicolumn{2}{|c|}{ القياس البعدي } & \multicolumn{2}{|c|}{ القياس القبلي } & \multirow[b]{2}{*}{ وحدة القياس } & \multirow{2}{*}{\multicolumn{2}{|c|}{ المتغيرات }} \\
\hline & الالاحري افي & الحستبط & الالمعر افياري & المستوسطي & & & \\
\hline$* \Lambda_{.} . \leqslant$ &..$r$ & $7 . \mu r$ & $\cdot{ }^{\mu}$ & V.r. & ثانية & اختبار · r متر عدو من البدء المنطلق & \\
\hline$* \wedge .7 \Lambda$ & $\because 9$ & 1.19 & $\because 1$ & 1.0 & متز & اختبار الوثب العريض من الثبات & $E:$ \\
\hline$* 0.0 Y$ & $1 . r \mu$ & $0.7 V$ & $1 . \mu 1$ & $r . \wedge$ & سم & اختبار ثنى الجذع أماماً أسفل من الوقوف & $E$ \\
\hline$* \varepsilon .0$ &.$Y Y$ & $9.0 Y$ & 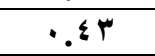 & $1 \cdot .9^{9}$ & ثنانية & جري زجزاجي & $\underline{\underline{E}}$ \\
\hline$* 11.47$ & $* . .19$ & V.V. &. .17 & ^.£. & درجة & اختبار الدوائر الرقمية & $\underline{E}$ \\
\hline$* \Lambda .7 V$ &. $.0 \wedge$ & $\{.0 \leqslant$ & $\cdot . \wedge V$ & r. YO & درجة & درجة الاقتر اب & \\
\hline$* \Lambda . \mu \nu$ &. .19 & $r .9 Y$ & $. . V \leq$ & r... & درجة & درجة الارتقاء & $G: G$ \\
\hline$* V . Y \leq$ & $\because \vee \wedge$ & $\varepsilon . Y_{1}$ &.. $\mathrm{TV}$ & $1.9 r$ & ل درجة & درجة الطيران & क \\
\hline$* q . r Y$ &..$\$ 9$ & $\leqslant .7 V$ &. $\mathrm{Vo}$ & 1.10 & درجة & درجة الهبوط & \\
\hline$* 07.11$ & $\because .0$ & r.o. & $\because \cdot \varepsilon$ & $r . r v$ & متر & المستوى الرقمي للوثب الطويل & \\
\hline
\end{tabular}

Y.Y. . = قيمة " ت " الجدولية عند مستوى

ويتضح من الجدول (r) وجود فروق ذات دلالة إحصائية بين القياس القبلي والقياس البعدي في القدرات البدنية والمستوي المهارى والرقمي للوثب الطويل قيد البحث لدي المجموعة التجريبية ولصالح القياس

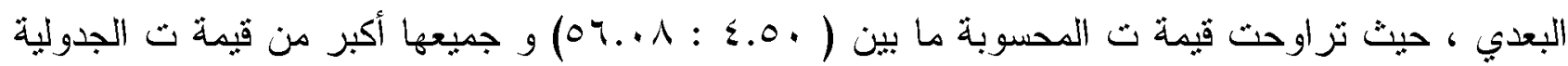
وذلك عند مستوي معنوية ه. . . . 
مجلة بحوث التربية الرياضية

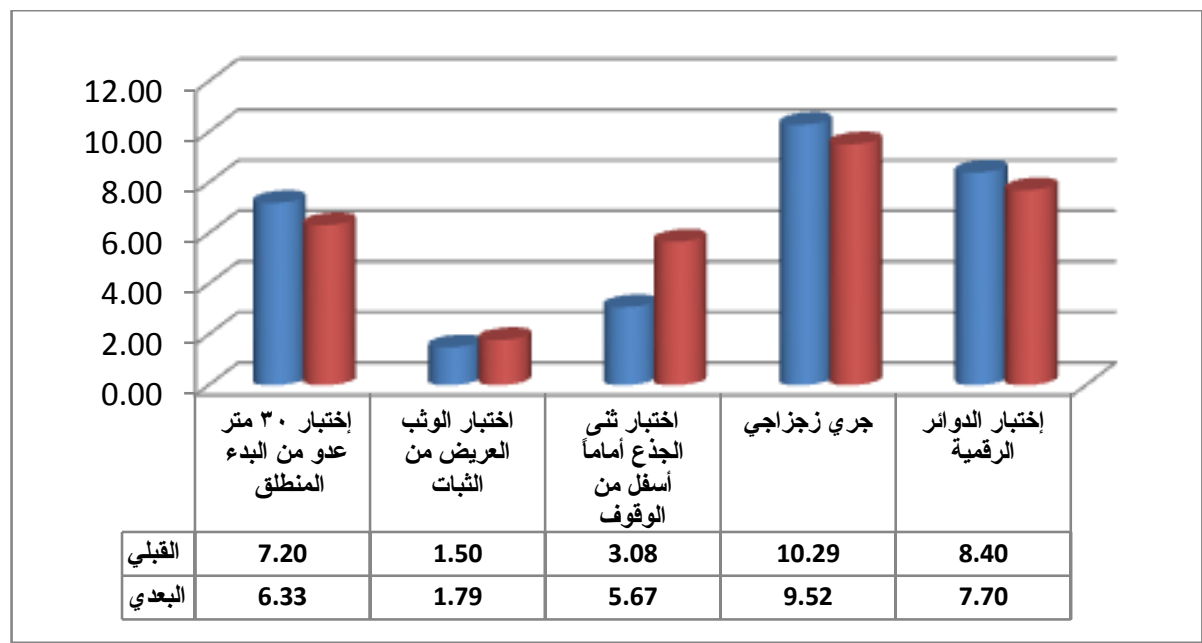

شكل (1)

يوضح متوسط القياس القبلي والبعدي في القدرات البدنية للمجموعة التجريبية قيد البحث

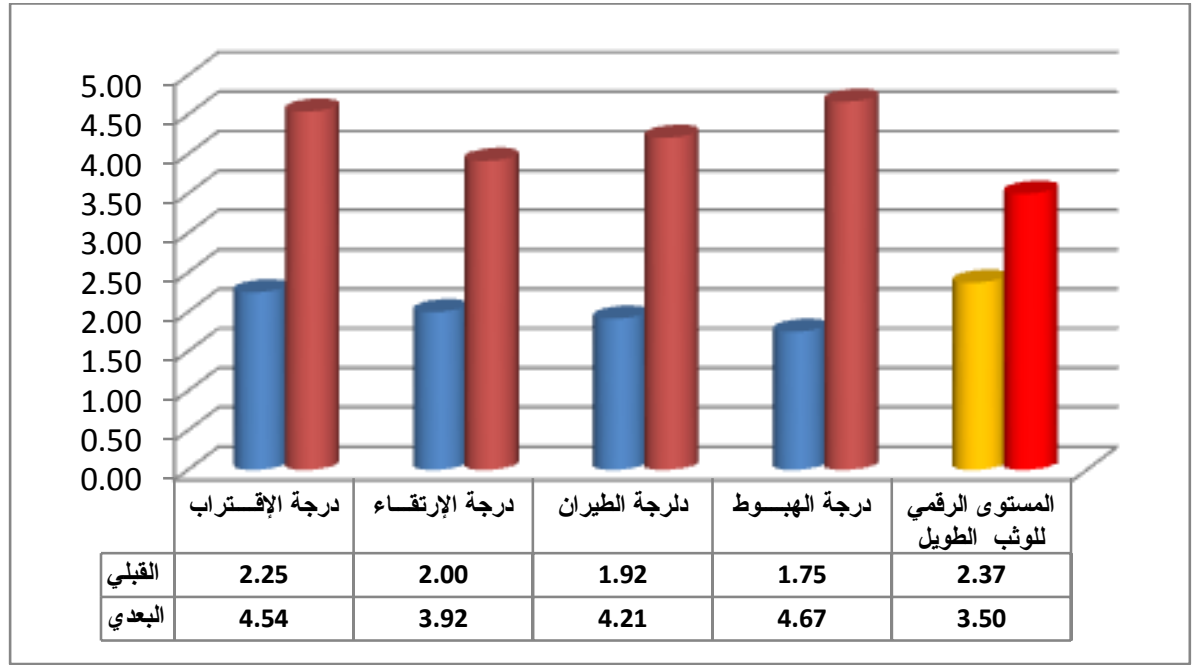

شكل (r)

يوضح متوسط القياس القبلي والبعدي في المستوي المهارى والرقمي للوثب الطويل للمجموعة التجريبية قيد البحث. 
جدول (ई)

دلالة الفروق بين القياس القبلي و البعدي في القدرات البدنية والمستوي المهارى والرقمي للوثب الطويل

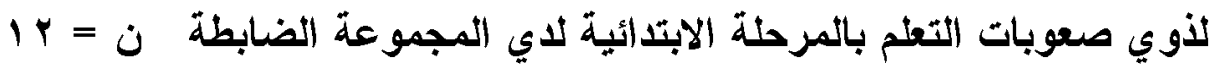

\begin{tabular}{|c|c|c|c|c|c|c|c|}
\hline \multirow{2}{*}{ "قدة " قدالتها } & \multicolumn{2}{|c|}{ القياس البعدي } & \multicolumn{2}{|c|}{ القياس القبلي } & \multirow[b]{2}{*}{ وحدة القياس } & \multirow[b]{2}{*}{ المتغير ات } & \\
\hline & الالمعرار افي & المستوسطي & المعياري الفيد & الحستوسطي & & & \\
\hline Y.11 &.$M$ & V.1. & • & $V . \leqslant 1$ & ثُاتية & اختبار · r متر عدو من البدء المنطلق & \multirow{5}{*}{$\begin{array}{l}E: E \\
E \\
E \\
E \\
E \\
E\end{array}$} \\
\hline$* 4.71$ &. .9 & 1.00 &. .9 & 1.20 & متر & اختبار الوثب العريض من الثبات & \\
\hline. .71 & $1 . r$. & r.7V & $1 . \leqslant \wedge$ & r.ro & 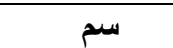 & اختبار ثنى الجذع أماماً أسفل من الوقوف & \\
\hline 1.1 &..$\leq r$ & $1 \cdot \cdots$ & .41 & $1 \cdot .1 \mathrm{~V}$ & ثانية & جري زجزاجي & \\
\hline $1.1 \varepsilon$ &. .99 & $\Lambda . r \cdot$ & $\cdot r \cdot$ & A.rr & درجة & اختبار الدوائر الرقمية & \\
\hline r.Ir & .9 & r.9r & $\because V Y$ & r.lV & درجة & درجة الاقتر اب & \multirow{5}{*}{ 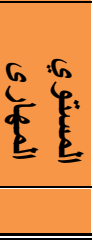 } \\
\hline $1 . r r$ &. .70 & r. $.7 \mathrm{~V}$ & $\cdot . \wedge V$ & r. ro & درجة & درجة الارتقاء & \\
\hline$* r . \wedge$. & $\because \vee \wedge$ & Y.TV & $\because V Y$ & $1 . \wedge r$ & درجة & درجة الطير ان & \\
\hline$* 4.7 r$ & 1.1 & r. rq &.$\wedge 9$ & $1.7 \mathrm{~V}$ & درجة & درجة الهبوط & \\
\hline$* Y 1 . \Lambda$. & $\because \cdot 7$ & $Y . \wedge 7$ & $\because \cdot 0$ & r.ru & 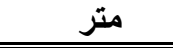 & المستوى الرقمي للوثب الطويل & \\
\hline
\end{tabular}

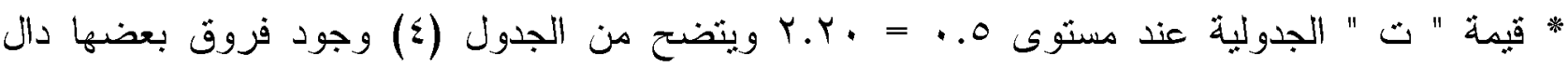
وبعضها غبر دال إحصائيا بين القباس القبلي والقباس البعدي و البعدي في القدرات البدنبة والمستوي المهارى و الرقمي للوثب الطويل قيد البحث لدي المجموعة الضابطة ولصالح القياس البعدي ، حيث نراوحت قيمة ت

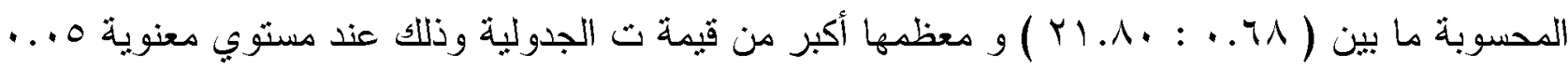

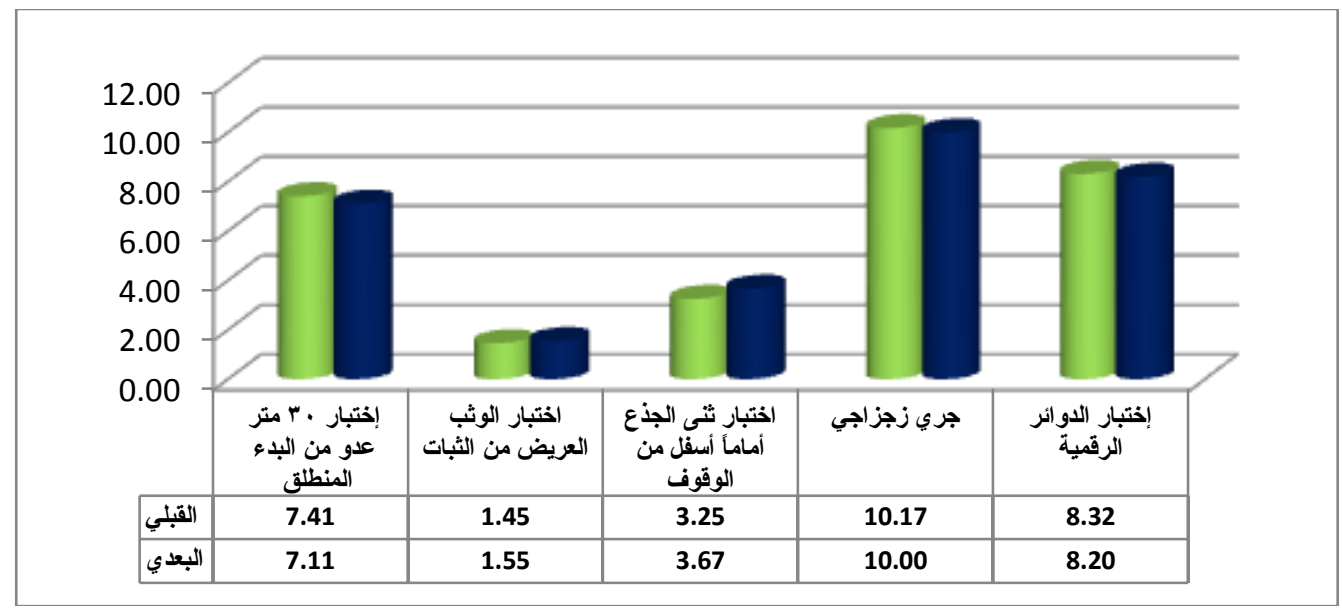

شكل (r) (1) (1)

يوضح متوسط القياس القبلي والبعدي في القدرات البدنية للمجموعة الضابطة قبد البحث 
مجلة بحوث التربية الرياضية

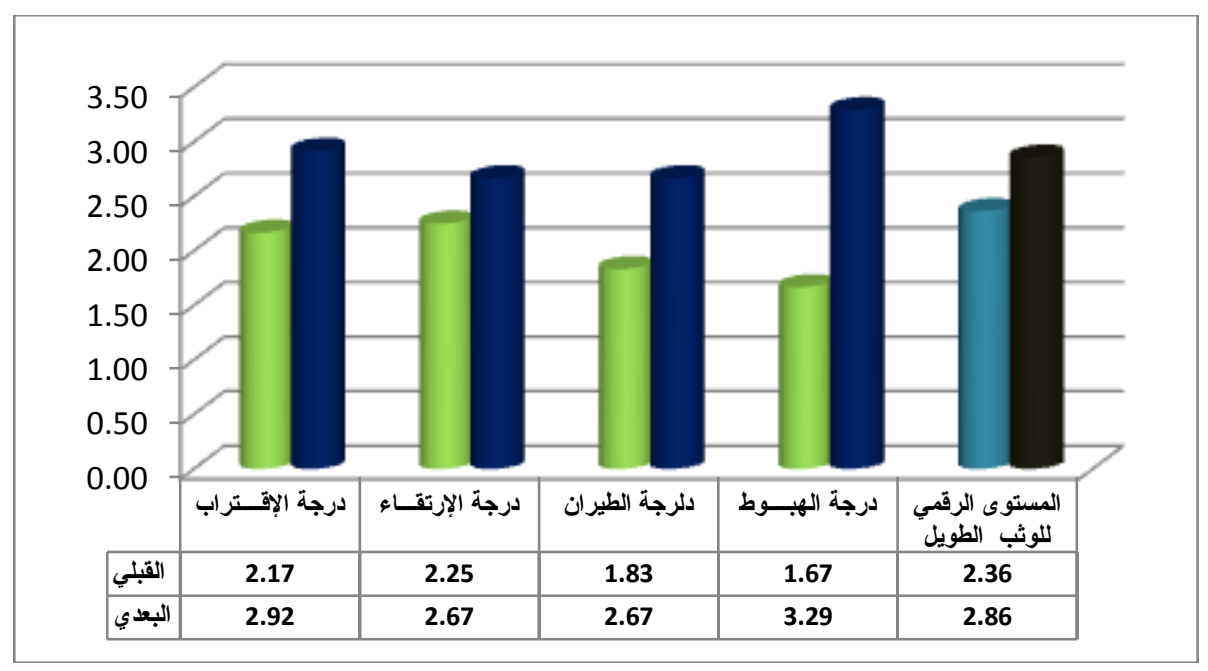

شكل (๕)

يوضح متوسط القياس القبلي والبعدي في المستوي المهارى والرقمي للوثب الطويل للمجموعة الضابطة قبد البحث

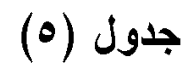

دلالة الفروق بين القياسين البعايين لمجموعتي البحث الضابطة والتجريبية في القدرات البدنية والمستوي

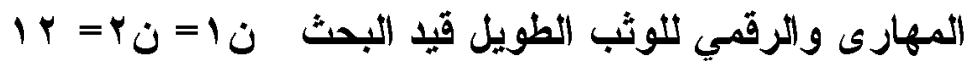

\begin{tabular}{|c|c|c|c|c|c|c|c|}
\hline \multirow{2}{*}{ 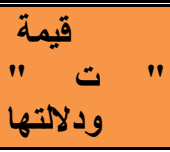 } & \multicolumn{2}{|c|}{ المجموعة الضابطة } & \multicolumn{2}{|c|}{ المجموعة التجريبية } & \multirow[b]{2}{*}{ وحدة القياس } & \multirow{2}{*}{\multicolumn{2}{|c|}{ المتغير ات }} \\
\hline & 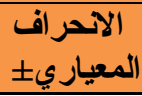 & الحستوسطي & الالمعر افياري & الحستوسطي & & & \\
\hline$* \eta . Y \wedge$ & $\cdot . M$ & V.1. & $\cdot . \mu$ & $7 . \mu r$ & ثانية & اختبار · ب متر عدو من البدء المنطلق & \\
\hline$* V .00$ &. .7 & 1.00 & $\because 9$ & 1.89 & 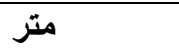 & اختبار الوثب العريض من الثبات & $\underline{E}$ \\
\hline$* r . \wedge V$ & $1 . r$. & r.7V & $1 . r \mu$ & $0.7 \mathrm{~V}$ & 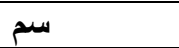 & اختبار ثنى الجذع أماماً أسفل من الوقوف & $\underline{E}=$ \\
\hline$* \Psi . \varepsilon r$ &..$\leqslant r$ & $1 \cdot \cdots$ &.$Y Y$ & $9.0 Y$ & ثانية & 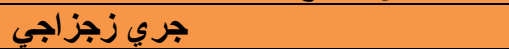 & E: \\
\hline$* \varepsilon .94$ &..$r q$ & ^.r. & .19 & V.V. & درجة & اختبار الدوائر الرقميةة & \\
\hline$* 0 . Y 0$ & .9 & r.qY & $.0 \wedge$ & $\varepsilon .0 \leqslant$ & درجة & ل درجة الاقتراب & $6: 6$ \\
\hline *\&.YY & .70 & Y. TV &. .19 & r.qr & درجة & درجة الارتقاء & $\xi \xi^{2}$ \\
\hline$* \varepsilon . \wedge \varepsilon$ &.$\vee \wedge$ & Y.7V &..$\vee \wedge$ & E.Y & درجة & درجة الطيران & \\
\hline$* \varepsilon . Y \varepsilon$ & 1.1 & r.rq &. .29 & $\varepsilon .7 V$ & درجة & درجة الهبوط & \\
\hline *YV.Y. & .97 & $r . \wedge \neg$ & $\because 0$ & r.o. & 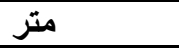 & المستوى الرقمي للوثب الطويل & \\
\hline
\end{tabular}

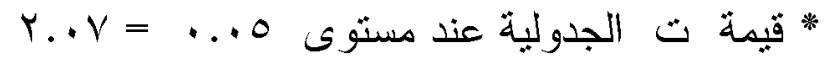

يتضح من جدول رقم (0) وجود فروق دالة إحصائيا بين المجموعتين التجريبية والضابطة في القياس

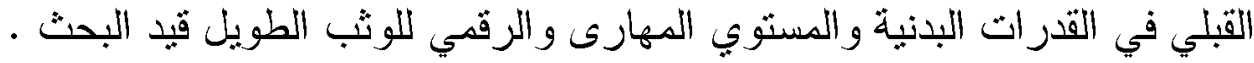




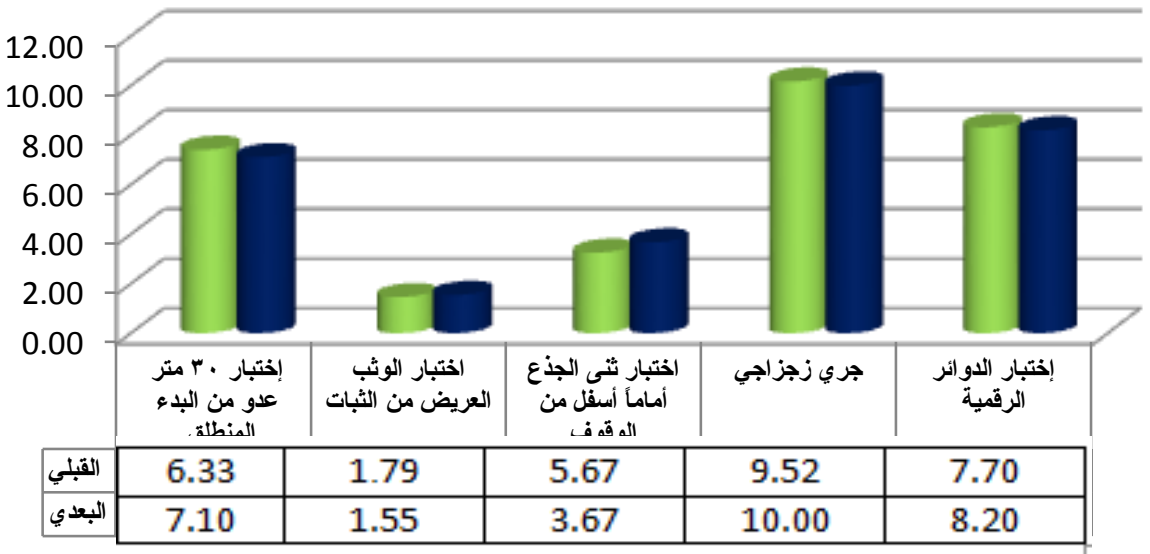

شكل (ن) (ن)

يوضح متوسط القياسين البعديين للمجموعتين التجريبية والضابطة في القدرات البدنية قيد البحث.

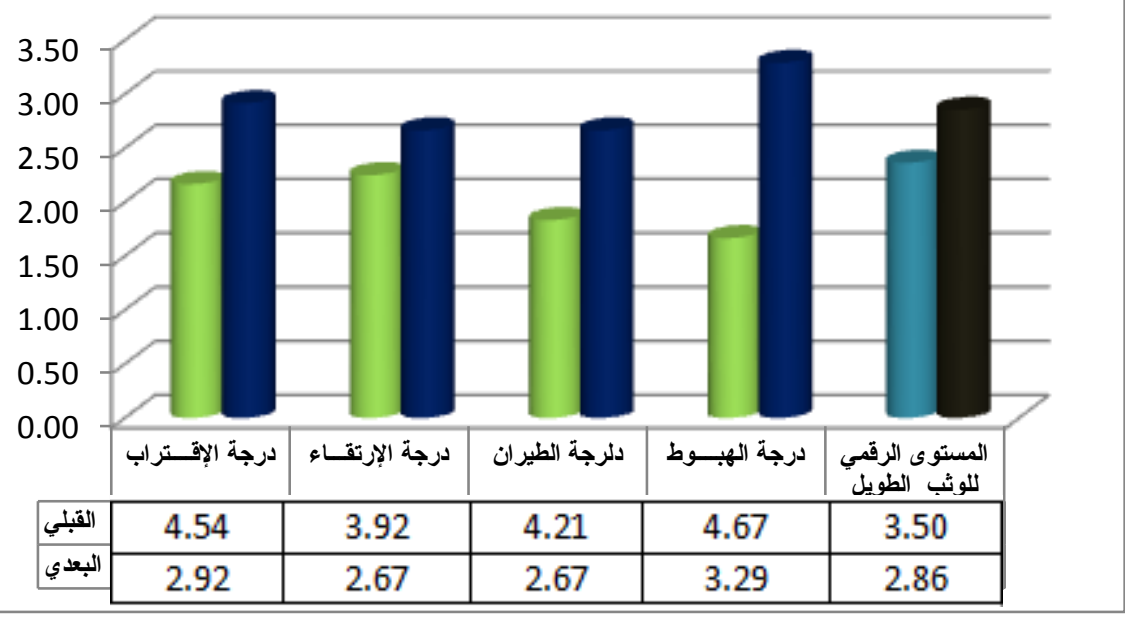

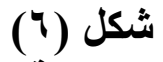

يوضح متوسط القياسين البعديين للمجموعتين التجريبية والضابطة في المستوي المهارى والرقمي للوثب

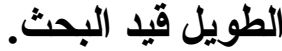

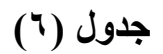

نسبة التحسن المئوية في القدرات البدنية والمستوي المهارى و الرقمي للوثب الطويل قيد البحث للمجموعتين ( التجريبية و (الضابطة ) قيد البحثي.

\begin{tabular}{|c|c|c|c|c|c|c|c|c|}
\hline نسبة & \multicolumn{2}{|c|}{ المجموعة الضابطة } & \multirow{2}{*}{ التحسبة } & \multicolumn{2}{|c|}{ المجموعة التجريبيةً } & \multirow[b]{2}{*}{ القياس } & \multirow{2}{*}{\multicolumn{2}{|c|}{ المتغيرات }} \\
\hline التصن & البعديط & متوسط القبلي & & البعديط & متوسط القبلي & & & \\
\hline$\varepsilon .0$ & v. 1 . & $v . \leqslant 1$ & 19.10 & $7 . r \mu$ & $v_{.} r \cdot$ & ثانية & ختبار · r متر عدو من البدء المنطلق & \multirow{5}{*}{ 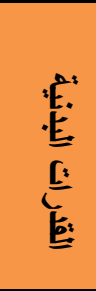 } \\
\hline 7.10 & 1.00 & $1 . \leqslant 0$ & 19.00 & 1.19 & 1.0 & متر & اختبار الوثب العريض من الثبات & \\
\hline Ir.Ar & T.TV & r.ro & $\wedge$ ^r.ı & $0.7 \mathrm{~V}$ & $r . \cdot \Lambda$ & سم & اختبار ثنى الجذاع أماماً أسفل من & \\
\hline $1.7 \varepsilon$ & $1 \cdot \ldots$ & $1 . .1 \mathrm{~V}$ & $v .0$. & $9.0 Y$ & $1 . .19$ & ثانية & جري زجزاجي & \\
\hline $1 . \varepsilon r$ & A.r. & $\Lambda . r r$ & ^.r. & v.v. & $\Lambda_{.} \varepsilon \cdot$ & درجة & اختبار الاو ائر الرقمية & \\
\hline$r \varepsilon .7 r$ & r.qr & Y.IV & $1 \cdot 1.9$. & $\varepsilon .0 \leqslant$ & Y.YO & درجة & لدرجة الاقتراب & \multirow{5}{*}{$\underline{\underline{E}}$} \\
\hline $11.0 Y$ & Y.TV & Y.YO & $90 . \wedge r$ & $r .9 r$ & r... & درجة & درجة الارتقاء & \\
\hline$\leqslant 0 . \leqslant 0$ & Y.TV & $1 . \wedge r$ & 119.7. & $\varepsilon . Y_{1}$ & 1.94 & درجة & درجة الطيران & \\
\hline $9 V .0$. & $r . r q$ & $1.7 \mathrm{~V}$ & $174.8 \cdot$ & $\varepsilon .7 \mathrm{~V}$ & 1.20 & درجة & درجة الهبوط & \\
\hline$r \cdot . \wedge$. & 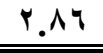 & r.ru & $\leq V . \leqslant V$ & r.0. & $r . r v$ & 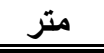 & توى الرقمي للوثب الطويل & \\
\hline
\end{tabular}


ويتضح من الجدول السابق (آ) ما يلى : نوجد فروق في نسبة النحسن المئوية بين القياسين القبلي و البعدي للمجموعتين الضابطة والتجريبية في القدرات البدنية والمستوي المهارى و الرقمي للوثب الطويل قبد البحث ولصالح القباس البعدي للمجموعة التجريبية .

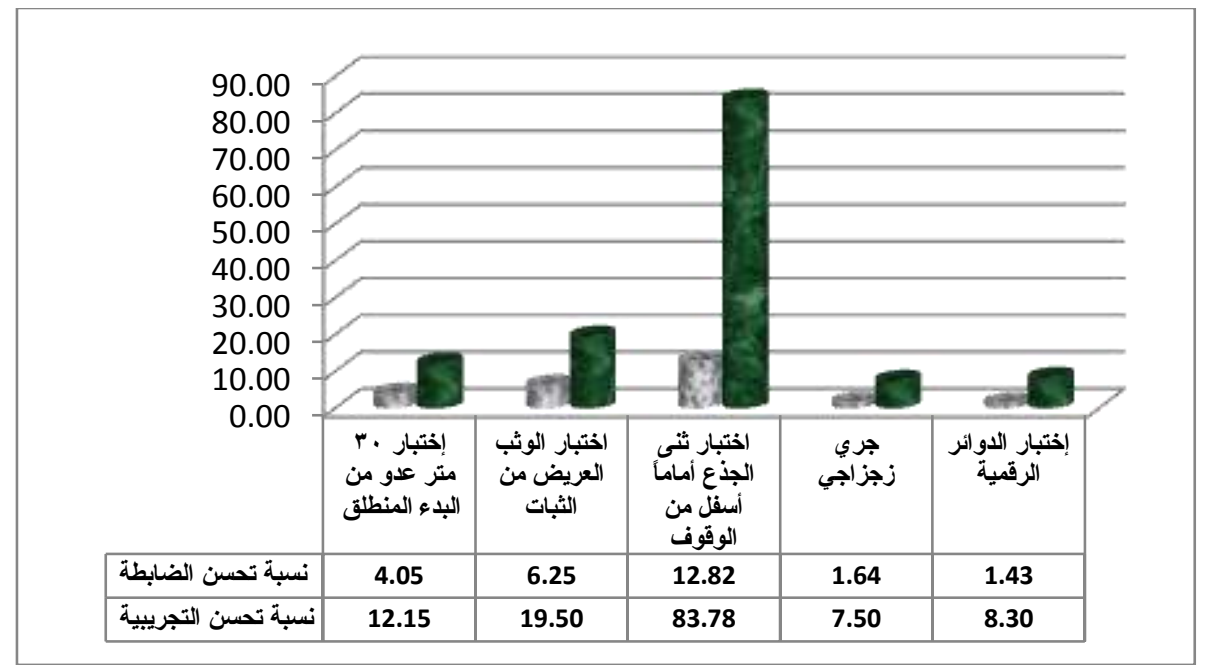

شكل شكل (v)

يوضح نسب التحسن في القرات البدنية لدي القياس القبلي والبعدي في المجموعتين (التجريبية -

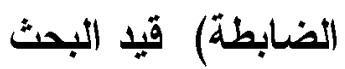

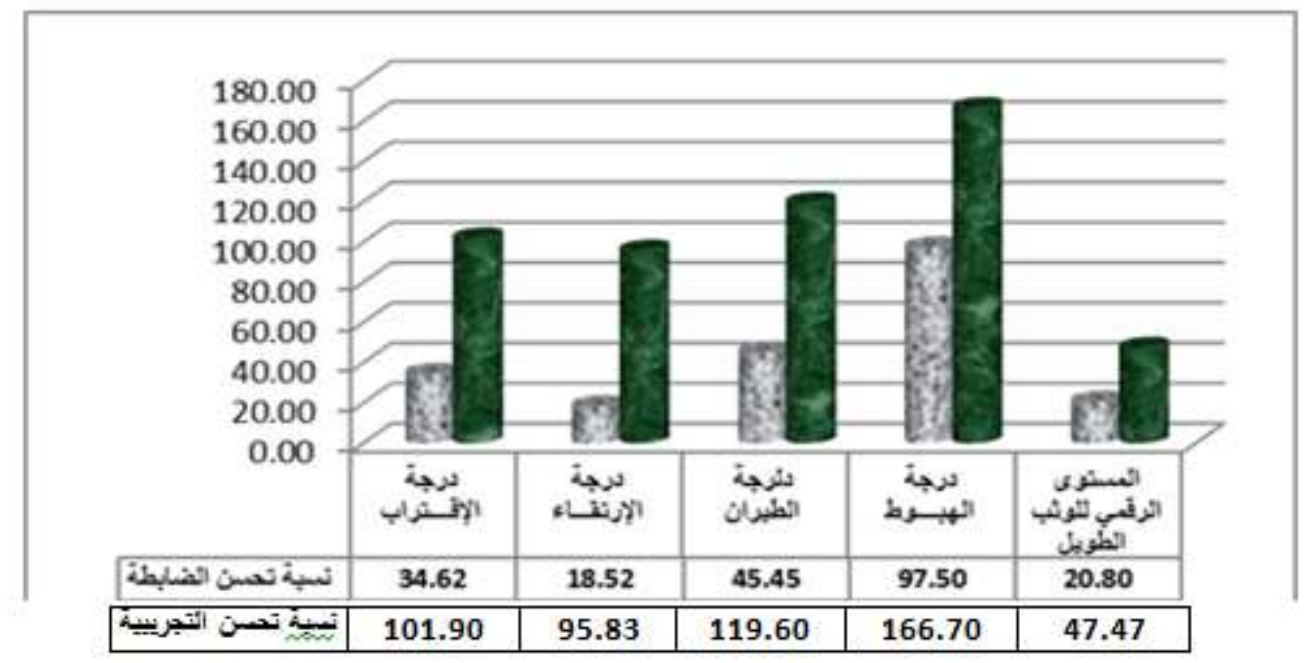

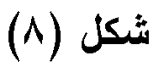

يوضح نسب التحسن في المستوي المهارى والرقمي للوثب الطويل لاي القياس القبلي والبعدي في المجموعتين ( التجريبية - الضابطة ) قيا البحث

r/\&

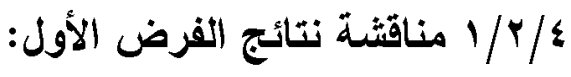


يتضح من الجدول رقم (r) والثكل رقم (Y، (Y) وجود فروق ذات دلالة إحصائية بين القياس القبلي و القياس البعدي والبعدي في القدرات البدنبة والمستوي المهارى والرقمي للوثب الطويل قيد البحث لدي

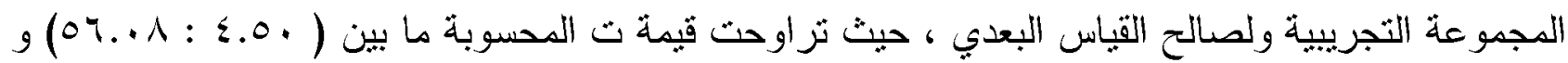
جميعها أكبر من قيمة ت الجدولية وذلك عند مستوي معنوية ه م. . . . يعزو الباحث وجود هذه الفروق المعنوية للمجموعة التجريبية في القياس البعدي عنها في القباس القبلي إلي تأثير البرنامج التعليمي المقترح باستخدام أسلوب العصف الذهني في تحسن القدرات البدنية و المستوي المهارى و الرقمي للوثب الطويل والذبي يتم من خلاله عرض المعارف والمعلومات المرثبطة بالمهارة قبد البحث باختصار ووضوح مع تدعبهما بمواقف ومشكلات تعليمية حقبقية يقوم التلامبذ بحلها من خلال خبرات حباتية موجودة لديهم بالإضافة إلى ثوفير المزيد من الحرية في التفكير و إنتاج أفكار جديدة هذا بالإضافة إلى مزيا جلسات العصف الذهني في الاتصال الجماعي والاستفادة هن أفكار الأخرين وتطويرها و الثي استفاد منها التلامبذ وانعكس بثكل إيجابي على أدائهم (المهارى - الرقمي ). بالإضـافة إلي أن البرنامج التعليمي يحتوي على العدبد من التمرينات النوعية الخاصة بمهارة الوثب الطويل في الجزء البدني من البرنامج والتي أثرث إيجابياً على الجانب البدني لعينة البحث التجريبية.

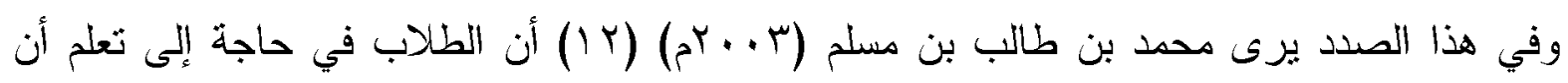
الأفكار يمكن تطيقها في مواقف جديدة ولأن الطلاب يقدمن حقائق وتفسيرات مختلفة فإنهم بعلمون أن ئن ئن المعلومات يمكن النظر إلبها من نواح مختلفة ولكن هذا لا بحدث إلا في بيئة صفية تركز على التعلم الجماعي وتحث على المثاركة فالثعاون بين الطلاب وتشجيع بعضهم البعض بخلق جواً مناسباً للاسثفادة من الأفكار وتسهيل عملية اكتساب الخبرات.

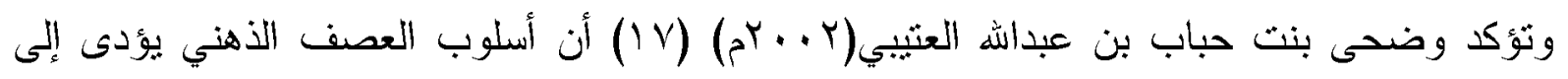
زيادة تحصبل المتعمين في جوانب التعلم المختلفة كما يؤدى إلى تتمية مستويات المعرفة لديهم أفضل من الأسلوب المعتاد.

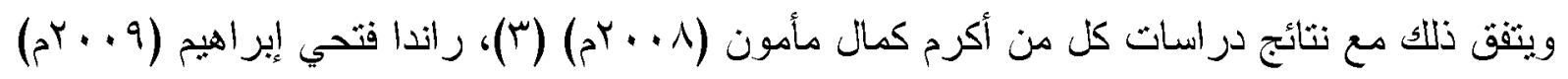
(0) ، على أن استخدام العصف الذهني يؤثز إبجابياً على مستوي القدرات البدنبة و والمستوى المهارى و الرقمي للوثب الطويل ومن ثم اكتساب النواحي المعرفية. وبذلك يتحقق صحة الفرض الأول والذى ينص على ما يلي: توجد فروف دالة احصائياً بين القياسين القبلي والبعدي للمجموعة التجرييية علي المنغيرات البدنية والمستوي المهارى والرقمي لمهارة الوثب الطويل لدي عينة البحث لصالح القياس البعدي. r/ץ/ يتضح من الجدول رثم (乏) والثكل رثم (س،؛) وجود فروق بعضها دال وبعضها غير دال إحصائياً بين القياس القبلي والقياس البعدي في القدرات البدنبة والمستوي المهارى والرقمي للوثب الطويل قبد البحث 
لاي المجموعة الضـابطة ولصالح القياس البعدي ، حيث ثراوحت ثيمة ث المحسوبة ما بين

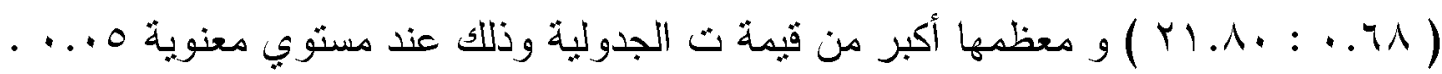
ويعزو الباحث تلاك النتائج إلي أن الطريقة التقليدية المتبعة والمتمثة في الثرح النظري و أداء النموذج (الأسلوب الأمري) لها ثأثثر ايجابي علي تحسين الاداء لدرجة معينة لمسابقة الوثب الطويل ثبد البحث فمن خلال إعطاء التلامبذ المعلومات والمعارف المرتبطة بمسابقة الوثب الطويل وعن طريق أداء نموذج صحيح من المعلم كان لها تأثير ايجابي في نكوين صورة واضحة إلي حد ما لمسابقة الوثب الطويل ثبد البحث وبالثالي يؤدي إلي تحسن بعض القدرات البدنية والوصول إلي تحسن طفيف في الأداء المهارى كما أن الطربقة التقليدية المتبعة في عملية التذريس والمتمثنة في الثرح و أداء نموذج و إعطاء فكرة واضحة عن كيفية الأداء السليم و أداء نموذج للمنعلمين ثم ثأني الممارسة والثكرار من جانب المتعلم و التغذية الراجعة من جانب المعلم وتصحيح الأخطاء بالإضافة إلي التدريبات البدنية الخاصة بمسابقة الوثب الطويل أدي بدورة إلي الارثقاء بالمستوي البدني بصفة عامة وخاصة القدرة البدنية( اختبار الوثب العريض من الثبات) وكذلك بمستوي الأداء المهارى إلي حد ما وبخاصة في مرحلة الطيزان و الهبوط. حيث أدث التدريبات البدنية الخاصة بمسابقة الوثب الطويل بأفضل ما بمكن مدا أدي إلي زيادة تحسن القدرات البدنية والمسنوي المهارى والرقمي لصالح القباس البعدي عن القبلي للمجموعة الضـابطة.

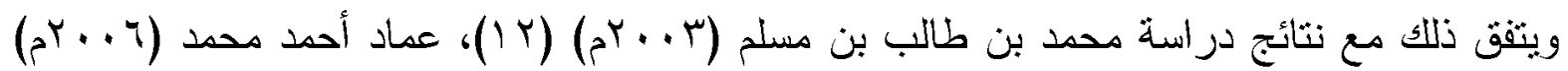

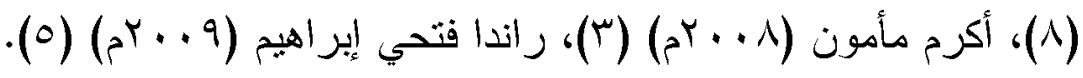
وبذلك بثحقق صحة الفرض الثاني والذى ينص على ما يلي: توجد فروق دالة احصائياً بين القباسين القبلي والبعدي للمجموعة الضابطة علي المتغيرات البدنية و المستوي المهارى والرقمي لمهارة الوثب الطويل لدي عينة البحث لصالح القباس البعدي.

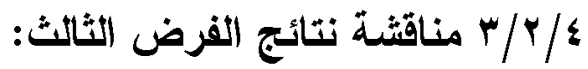

يتضح من جدول رقم (0) و النّكل رقم (0، (1) وجود فروق دالة إحصائيا بين المجموعثين التجربيية و الضـابطة في القياس القبلي في القدرات البدنية والمسثوي المهارى و الرقمي للوثب الطويل قبد البحث . ويرجع الباحث ذلك إلى أن البرنامج المقترح تم تصميمه بطريقة تساعد على تصور المهارة من خلا طرح مثكلات فعلية على التلامبذ ودعوثهم إلى اقتراح وابنكار أفضل الحلول لها بطريقة علمبة منظمة وبشكل ابتكاري وذلك لأن العصف الذهني بعنى التصدي النشط للمشكلة مما أعطى التلاميذ تصورات واضحة ووسيلة لثأدية المهارة بالصورة الصحيحة، كما ساعد على فهم المهارة وجعل عملية الثعليم سهلة وشيقة كما اعطاهم حرية التعبير عن أفكارهم عن طريق زيادة دافعية التلامبذ باسنثارة الجهاز العصبي لتلاميذ المجموعة التجريبية بينما تقتقر الطريقة التقليدية التي خضعت لها المجموعة الضابطة لهذه الأسباب حيث اعتمدت على أسلوبي الثرح اللفظي وأداء النموذج العملي فقط. 
كما يعزو الباحث تفوق أفراد المجموعة التجريبية إلى أن استخدام العصف الذهني يثميز بثقسيم المهار ات إلى مثكلات ومهارات صغيرة في ضوء الثسلسل المنطقي لها بطريقة منظمة ومتثابعة وربطها بالمعلومات الأساسية بطريقة مباشرة في شكل أفكار متعددة قابلة للتطبيق، مما يساعد التلامبذ على التركيز وتفه كل جزء وتعلمه بسهولة وفى هذا الصدد يشير أحمد قنديل (ب99 (م) أن إطلاق العنان للفكر بجعل القرد يفكر فيما وراء الحلول التقليدية وينظر إلى المشكلة من زوايا متعددة وبطرق جديدة مما يؤدى إلى حل مشكلات قديمة مثعلقة بالمثكلة أو بمو اقف لم يثم الثوصل إلى حلها في الماضي. (Y: OV)

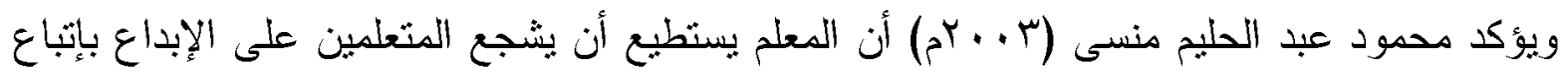
أسلوب العصف الذهني وذلك لإنتاج أفكار جديدة عن طريق استجابتهم للأسئة التي توجه إلبهم، واستثارتهم لإعطاء أكبر قدر من الاستجابات و إتاحة مناخ خال من ثوجيه وثتويم الاستجابات. (9 19: 9) وهذا يتفق مع نتائج دراسات كلا من ، وضحى بنت حباب بن عبداله العتيبي (Y (. .Yم) (IV)،

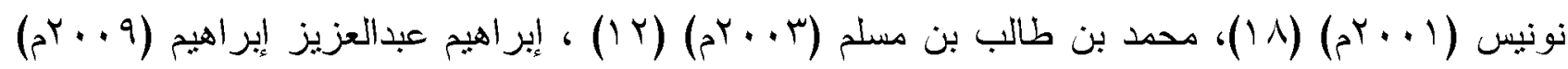
(1) ، راندا فتحي إبراهيم (Y (. (Y) (0) في أن العصف الذهني له ثأثير إيجابي على ثعلم المهارات التعليمية وإتقانها بالإضافة للإبداع فيها واكتساب المعارف المرتبطة بها بشكل أسهل وأكثر إيجابية دن

الطرق التعليمبة التقليدية. وبذلك بتحقق صحة الفرض الثالث و الذى بنص على ما يلي: توجد فروق دالة احصائياً بين منوسطي القباسين البعديين للمجموعنين الثجريبية والضابطة علي المثغيرات البدنية والمستوي المهارى و الرقمي لمهارة الوثب الطويل لدي عينة البحث لصالح المجموعة التجريبية.

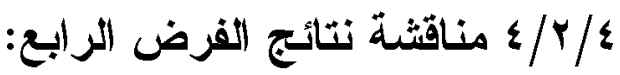

يتضح دن الجدول رقم (Y) والثكل رقم (A،V) توجد فروق في نسبة التحسن المئوية بين القياسين القبلي والبعدي للمجموعنين الضابطة والثجريبية في القدرات البدنية والمستوي المهارى والرقمي للوثب الطويل قيد البحث ولصالح القباس البعدي للمجموعة التجريبية . ويعزو الباحث إلي أن هذه الفروق ونسب التثدم في القياسات البعدية للمجموعة التجريبية إلى الطريقة المتبعة باستخدام العصف الذهني التي أهنمث بالعمليات العقلية العليا كالإستاج الاستثراء و التفسبر والتحويل و التطبيق والاستدلال و التحليل وغيرها من العمليات العقلية التي ينمبها أسلوب العصف الذهني، فضدلا عن عدم اهنمام الطريقة الثقليدية بالجوانب النفسية والحسية للتلاميذ كالتصور و التخيل والإدراك مما يجعل أثز التعلم والاحثفاظ بالمعلومات أقل مقارنة بأسلوب العصف الذهني.

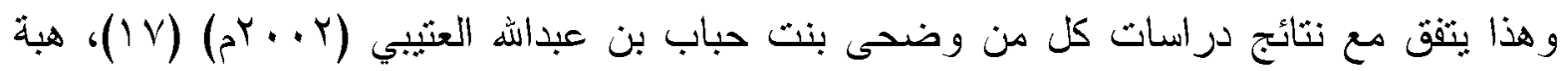

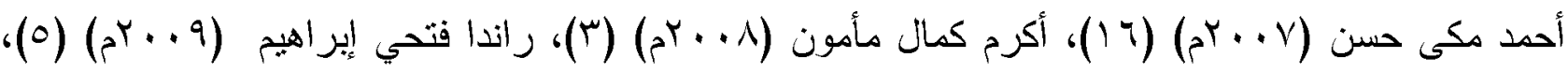
مصطفى مسعد محمد نصار (· (1. (10) (1). 
لكل هذه الأسباب بنحقق صحة الفرض الرابع و الذى ينص على ما يلي: توجد نسب تحسن مثفاوتة بين القياسين القبلي والبعدي في كل من المجموعثن التجريبية والضدابطة في جميع متغيرات البحث.

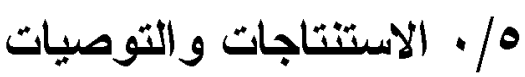

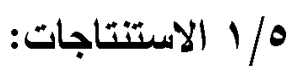
في ضو اء أهداف البحث وفروضه وفى حدود عينة البحث واستناداً الى المعالجة الإحصائية وما أثثارت اليه من نتائج يمكن استنتاج الآتي: 1- البرنامج التعليمي المقترح باستخدام العصف الذهني أدى إلى تحسن مستوى القدرات البننية و الأداء

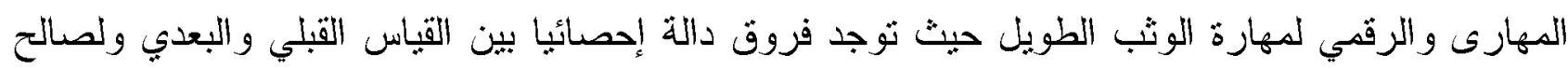
القياس البعدي في المجموعة التجريبية وفي جميع المتغيرات.

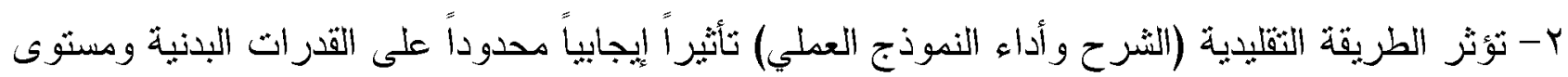

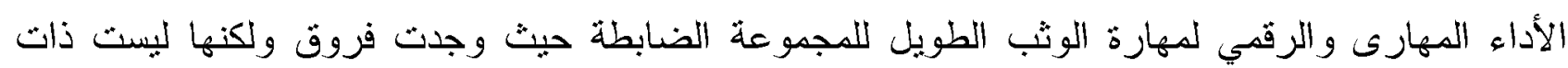
دلالة إحصائية. ب- استخدام العصف الذهني أكثر تأثير أ على سرعة تعلم مهارة الوثب الطويل في أغلب متغيرات البحث من

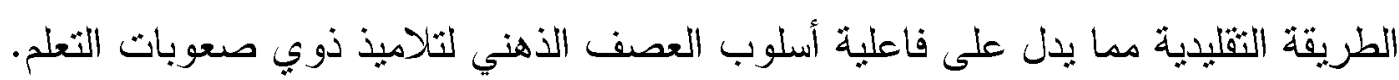
ـ - تفوق المجموعة التجريبية على المجموعة الضابطة في نسب التحسن في تعليم مهارة الوثب الطويل. r/0

في ضوء ما أظهرته نتائج البحث والاستنتاجات التي تم التوصل إليها يوصي الباحث بالآتي:

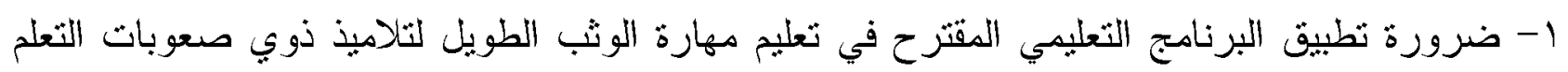
في المرحلة الابتدائية. ب- نطبيق برامج تعليمبة مشابهة باستخدام العصف الذهني في تعلم مسابقات المبدان و المضمار الأخرى عي

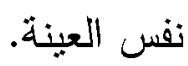
r- الاهتمام باستخدام طرق التدريس التي تساعد على تكوين اتجاهات إيجابية لاى المتحلمين من ذوي

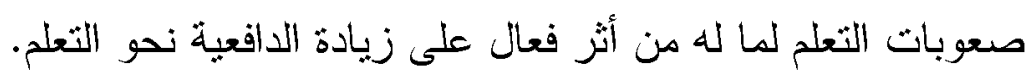

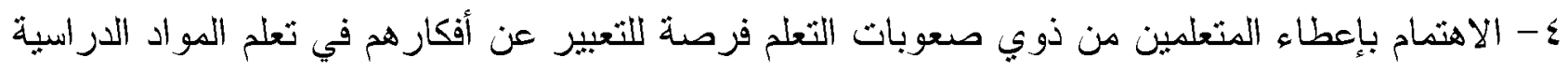
التي يدرسو ها مما يجعل لايهم الدافع القوى للتعلم ويرفع من ثقتهم بأنفسهر.

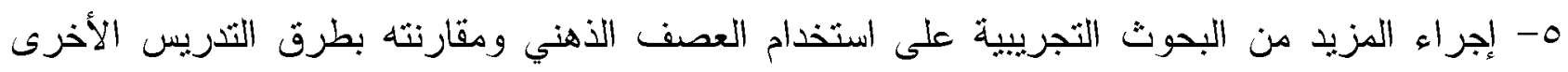
لتحقيق و إثبات مدى فاعلينه في تخصصات أخرى التهر. 


\section{أولا: المراجع العربية}

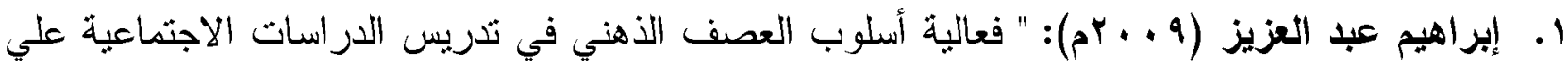
تتمية مهار ات التفكير الإبداعي لاي تلاميذ المرحلة الإعدادية " رسالة ماجستير غبر منشورة ، كلبة الثية

التربية، جامعة المنوفية.

r. أحمد إبراهيم قتديل (r (99 1م): التدريس الابتكاري، دار الوفاء للطباعة و النشر، القاهرة.

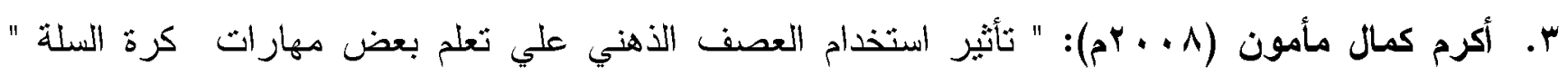

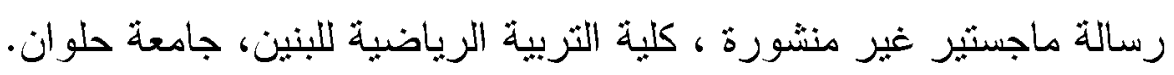

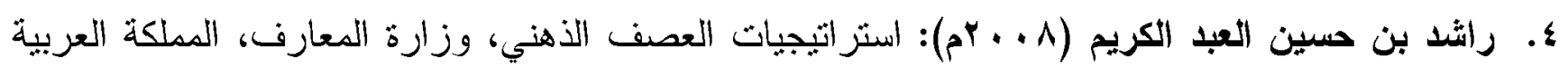
السعودية.

ه. ر رندا فتحي إبراهيم سعيد (q . + rم): " تأثير استخدام العصف الذهني علي التحصيل المعرفي وعلاقته

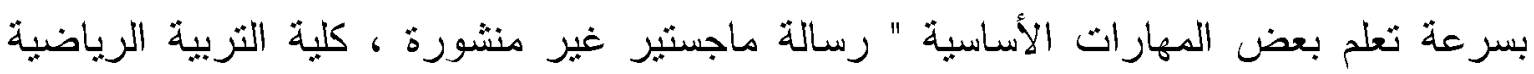
لالبنات، جامعة الزقازيق.

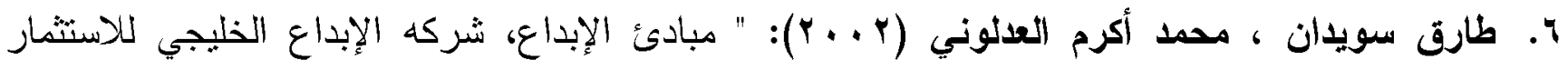

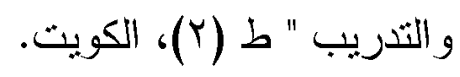

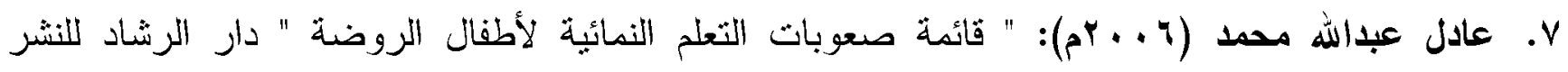

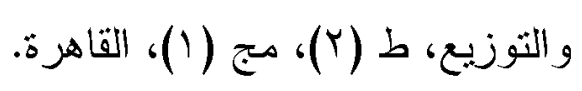

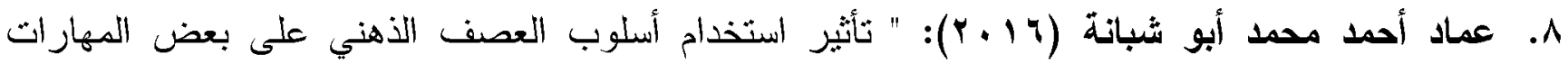

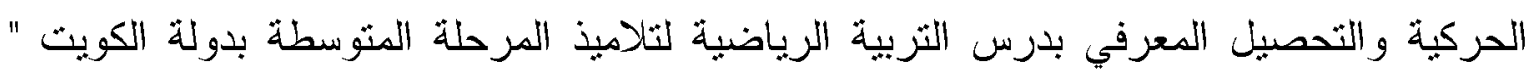
مجلة كلية التزبية الرياضية بنين جامعة الزقازيق. 9. عماد سعيد المحلاوي ( . . rم): " ثأثير العصف الذهني للمشكلة والاكتثاف الموجه في كل من التحصيل

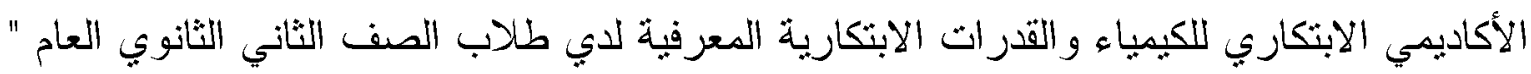
رسالة ماجستير غير منشورة ، كلية التزبية - كفر الثشيخ، جامعة طنطا.

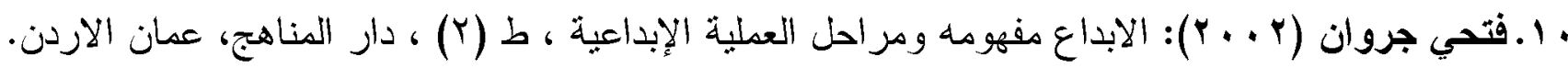

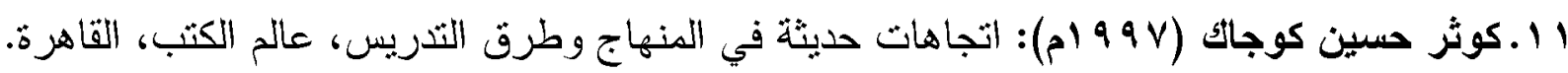

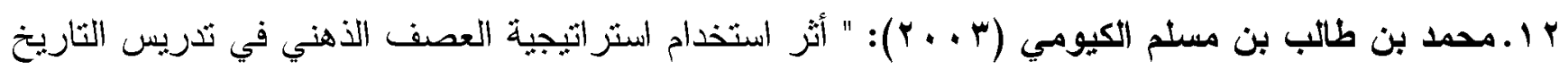

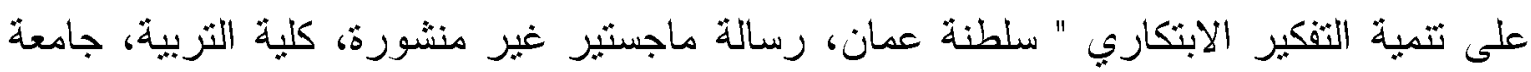
السلطان ثابوس. 
ب ا..محمد محمد احمد الضهراوى (999 19): " نأثثر استخدام التعلم التعاوني علي التعلم والاتجاه نحو بعض مسابقات ألعاب القوب لطلاب المرحلة الثانوية " مجلة علوم الثربية الرياضية للبنين، جامعة الز قازيق.

ع اـ محمود عبد الحليم منسي (r + . rم): الإبداع والموهبة في التعليم العام، دار المعرفة الجامعية، الإسكندرية. ه ا.مصطفي مسعد محمد نصار ( (1 +rم): " بناء برنامج نعليمي باستخدام أسلوب العصف الذهني في اكتساب المهارات التدريسية للطالب المعلم بشعبة التدريس بكلية التربية الرياضبة" رسالة ماجسنير غير

منتورة، كلية التربية الرياضية ، جامعة طنطا.

צا ـ هبة أحمد مكي حسن (V + . rم): " فاعلية استخدام العصف الذهني والمثابهات في تدريس الدراسات الاجتماعية وأثز ذلك علي تدريس الدراسات وأثز ذلك علي تتمية التحصبل و القدرة الاستدلالية في التفكير لدي تلاميذ المرحلة الإعدادية " رسالة ماجستير غير منشورة ، كلبة التربية، جامعة أسوان.

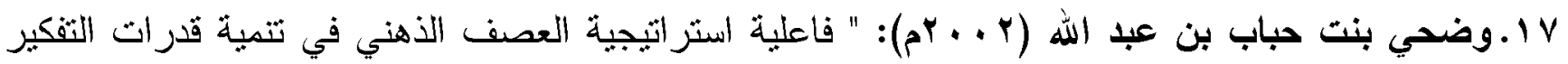
الابتكاري و التحصيل الدراسي في مادة العلوم لدي طالبات الصف الأول المتوسط بمدينة الرياض" رسالة ماجستير غير منشورة ، كلية البنات- كلبة التربية، جامعة الأمير سلطان.

\section{ثانياً المراجع الأجنيية}

1^-Nonis ' Aileen et al. ( ץ.. o): Technology and Teacher Preparation Creating Student Involvement and Creativity, The University of Tennessee, U.S.A.

19-Osborn, A.F. (ץ..1): Applied Imagination: Principles and Procedures of Creative Thinking, Serbers's Ltd, New York, U.S.A.

r.-Rowatt' Wade et al ( 9 q V): Perception of Brainstorming Groups: The Quality Over Quantity Hypothesis, The Journal of Creative Behavior, Vol. 31, No.2, p.p. 131-150. 